\title{
The feasibility and challenges of energy self-sufficient wastewater treatment plants ${ }^{1}$
}

Yifan $\mathrm{Gu}^{\mathrm{a}}$, Yue $\mathrm{Li}^{\mathrm{a}}$, Xuyao $\mathrm{Li}^{\mathrm{a}}$, Pengzhou Luo ${ }^{\mathrm{a}}$, Hongtao Wang ${ }^{\mathrm{a}}$, Zoe P. Robinson ${ }^{\mathrm{b}}$, Xin Wang ${ }^{\mathrm{c}}$, Jiang $\mathrm{Wu}^{\mathrm{c}^{*}}$ and Fengting $\mathrm{Li}^{\mathrm{a}}$

${ }^{a}$ State Key Laboratory of Pollution Control and Resource Reuse, Key Laboratory of Yangtze River Water Environment, Ministry of Education, College of Environmental Science and Engineering, Tongji University, Shanghai 200092, China

${ }^{b}$ School of Geography, Geology and the Environment, Keele University, Keele, Staffordshire ST5 5BG, UK

${ }^{c}$ College of Architecture and Urban Planning, Tongji University, 1239 Siping Road, Shanghai 200092, China

* Corresponding author:

Hongtao Wang, E-mail: hongtao@tongji.edu.cn, China.

Jiang Wu, E-mail: wujiang@tongji.edu.cn

\footnotetext{
${ }^{1}$ The short version of the paper was presented at ICAE2016 on Oct 8-11, Beijing, China. This paper is a substantial extension of the short version of the conference paper.
} 
Abstract Energy efficiency optimization is crucial for wastewater treatment plants (WWTPs) because of increasing energy costs and concerns about global climate change. Energy efficiency optimization can be achieved through a combination of energy recovery from the wastewater treatment process and energy saving-related technologies. Through these two approaches energy self-sufficiency of WWTPs is achievable, and research is underway to reduce operation costs and energy consumption and to achieve carbon neutrality. In this paper, we analyze energy consumption and recovery in WWTPs and characterize the factors that influence energy use in WWTPs, including treatment techniques, treatment capacities, and regional differences. Recent advances in the optimization of energy recovery technologies and theoretical analysis models for the analysis of different technological solutions are presented. Despite some challenges in implementation, such as technological barriers and high investment costs, particularly in developing countries, this paper highlights the potential for more energy self-sufficient WWTPs to be established in the future.

Keywords: wastewater treatment plants; energy consumption; energy recovery; energy self-sufficiency 


\begin{tabular}{|c|c|}
\hline \multicolumn{2}{|c|}{ Abbreviations: } \\
\hline $\mathrm{A} / \mathrm{A} / \mathrm{O}$ & Anaerobic-Anoxic-Oxic \\
\hline $\mathrm{A} / \mathrm{O}$ & Anoxic-Oxic system \\
\hline $\mathrm{AD}$ & Anaerobic digestion \\
\hline ANAMMOX & Anaerobic ammonium oxidation \\
\hline AnMBR & Anaerobic membrane bioreactor \\
\hline AWWT & Advanced wastewater treatment \\
\hline $\mathrm{BOD}_{5}$ & 5-day biochemical oxygen demand \\
\hline CANON & Completely autotrophic nitrogen removal over nitrite \\
\hline CAS & Conventional activated sludge \\
\hline CHP & Combined heat and power \\
\hline COD & Chemical oxygen demand \\
\hline DEAMOX & Denitrifying ammonium oxidation \\
\hline DEMON & Aerobic deammonification \\
\hline EBMUD & East Bay Municipal Utility District \\
\hline eSEA & Extended statistical entropy analysis \\
\hline FO & Forward osmosis \\
\hline GHG & Greenhouse gas \\
\hline GIS & Geographic information system \\
\hline HCWTP & Howard F. Curren Advanced Wastewater Treatment Plant \\
\hline HRAT & High rate algal system \\
\hline
\end{tabular}




\begin{tabular}{|c|c|}
\hline HRT & Hydraulic retention time \\
\hline IABF & Intermittently aerated biological filter \\
\hline LCA & Life cycle assessment \\
\hline MBBR & Moving bed biofilm reactor; \\
\hline MBER & Membrane bio-electrochemical reactor \\
\hline MBR & Membrane bioreactor \\
\hline MGD & Million gallons per day \\
\hline MFC & Microbial fuel cell; \\
\hline NAS & New activated sludge \\
\hline OD & Oxidation ditch \\
\hline OLAND & Oxygen limited autotrophic nitrification and denitrification \\
\hline PE & Population equivalent \\
\hline $\mathrm{PN} / \mathrm{A}$ & Partial nitrification/anammox \\
\hline POTWs & Publicly owned wastewater treatment facilities \\
\hline RO & Reverse osmosis \\
\hline $\mathrm{RT}$ & $1 \mathrm{RT}=3.517 \mathrm{~kW}$ \\
\hline SBR & Sequencing batch reactors \\
\hline SHARON & Single rector for high activity ammonia removal over nitrite \\
\hline SRT & Sludge retention time \\
\hline TAN & Total ammonia nitrogen \\
\hline THP & Thermal hydrolysis process \\
\hline WWTP & Wastewater treatment plant. \\
\hline
\end{tabular}




\section{Introduction}

Wastewater treatment plants (WWTPs) are widely implemented in most municipalities and companies to reduce harmful wastewater discharge into receiving water bodies [1]. Rojas et.al [2] pointed out that most WWTPs were designed to satisfy certain effluent quality requirements without sufficient consideration given to energy requirements, and that this is an area for improvement. However, the energy sufficiency of WWTPs is now becoming a topic of interest because sustainable supplies of both water and energy and corresponding carbon emission are critical for urban development $[3,4]$. The water-energy nexus has already become a hot topic in current policy research prompting a series of studies on the relationship between energy and water for sustainable development [5-10]. Increasing water resource stress in many parts of the world is increasing the use of energy for water conveyance, supply and treatment systems [11, 12]. Additionally, with the increasing attention to climate issues, conserving energy, improving energy efficiency and seeking alternative energy sources have become a common pursuit of global sustainable development $[13,14]$. WWTP is a typical case of interactions between water and energy. In most WWTPs, water quality is improved at the expense of significant energy input. WWTPs are frequently recognized as the largest independent energy consumers managed by municipalities [15]. Most major stages in WWTP, such as the collection and conveyance of wastewater, physical and chemical treatment, biological treatment, sludge treatment and discharge, require considerable energy [16]. In a conventional WWTP, 25\%-40\% of operating costs are attributed to energy consumption [3]. Moreover, corresponding greenhouse gas emissions by energy consumption in WWTPs also causes global concern [17-20].

Currently, energy efficiency optimization in WWTP is a popular topic in the scientific community [21-24]. Reducing the net energy input in WWTPs is a mandatory, not an alternative goal to water reuse [25]. Over the past few decades, energy recovery from wastewater has increased [12, 25-27]. Energy recovery or energy saving technologies have been also developed and applied in WWTPs. Energy self-sufficient WWTPs 
were studied to reduce operation cost, energy consumption and achieve carbon neutrality [15, 28-30]. In this paper, we address this issue through a systematic review of energy use and energy recovery in the wastewater treatment sector. The paper summarizes and analyzes the factors influencing energy use in WWTPs, including treatment techniques, treatment objects, capacities, and regional differences. We also investigate the energy that might be recovered from wastewater and the feasibilities and challenges of constructing energy self-sufficient WWTPs. This paper adds to our further understanding of the gap between energy self-sufficiency and the current situation of energy consumption in WWTPs in different regions worldwide.

\section{Current energy consumption of WWTPs}

All major procedures associated with wastewater treatment and sludge disposal technologies require energy, mostly as electricity, but also as natural gas or other fuels for pumping, mixing, separation, and treatment of wastewater and sludge (Fig. 1). The energy demand of a WWTP depends on the plant location, plant size, type of treatment process and aeration system, effluent quality requirement, age of plant, and knowledge of the operators [31, 32]. These influencing factors are summarized and discussed in detail in this section.

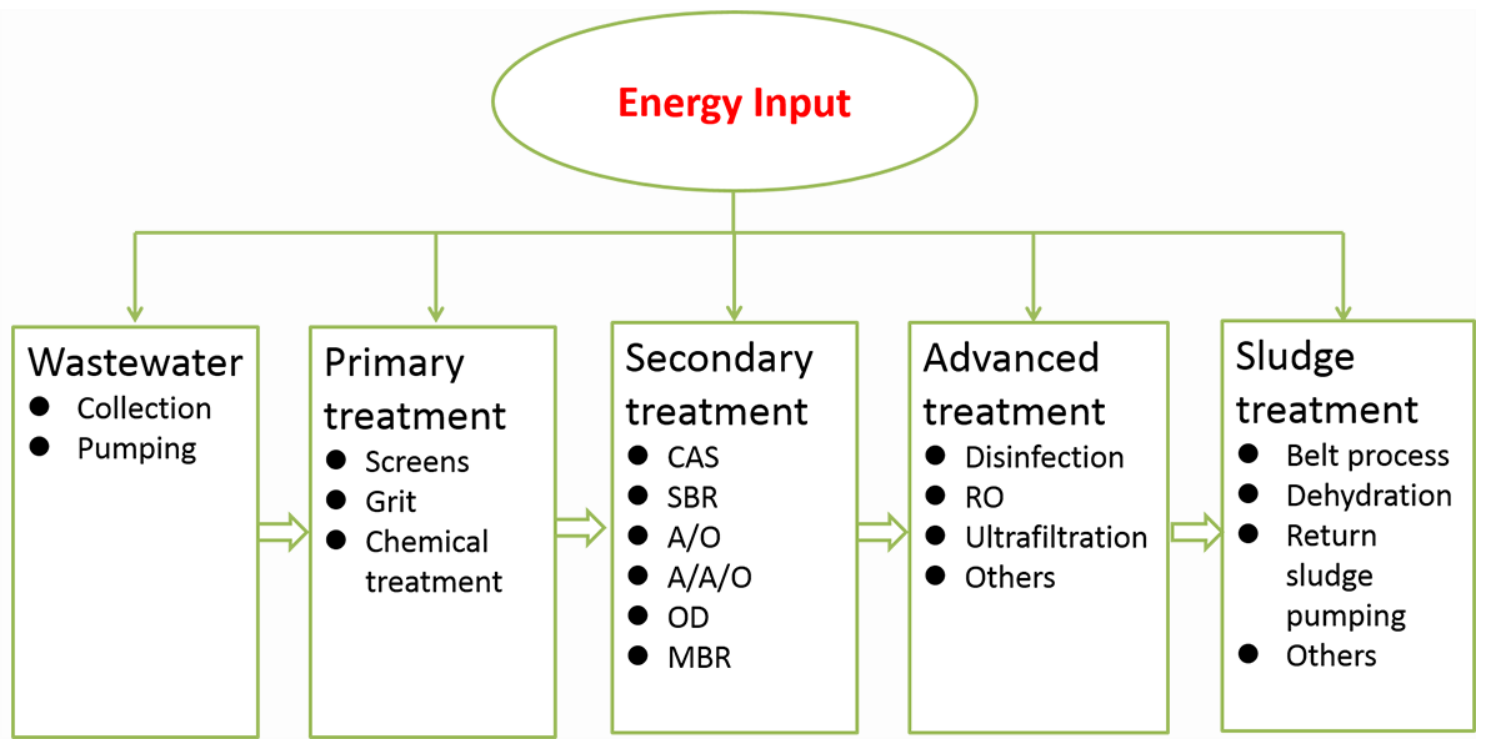

Fig. 1. Energy input in different wastewater treatment processes

\subsection{Energy consumption of WWTPs with different technologies}


A conventional municipal WWTP commonly consists of primary, secondary, and advanced treatment stages. Compared with other stages, the wastewater collection and primary treatment stage in WWTPs are less energy intensive and may be influenced by design and operation like transportation distance. For example, the energy intensity of raw wastewater collection and pumping during primary treatment is in the range of 0.02-0.1 kWh $/ \mathrm{m}^{3}$ in Canada, $0.045-0.14 \mathrm{kWh} / \mathrm{m}^{3}$ in Hungary, $0.04-0.19 \mathrm{kWh} / \mathrm{m}^{3}$ in New Zealand, and $0.1-0.37 \mathrm{kWh} / \mathrm{m}^{3}$ in Australia [33-35].

The energy consumption of secondary wastewater treatment stages depends mainly on the technologies used. For example, the average energy input of conventional activated sludge (CAS) treatment systems is 0.46 (Australia), 0.269 (China), 0.33-0.60 (USA), and 0.30-1.89 $\mathrm{kWh} / \mathrm{m}^{3}$ (Japan) [32]. Within a CAS treatment system, aeration in secondary treatment is the highest energy-consuming component of the treatment system [36]. In most medium and large WWTPs with CAS systems, aeration uses about $50 \%-60 \%$ of the total electricity consumption while sludge treatment consumes $15 \%-25 \%$ of the energy, and secondary sedimentation, including recirculation pumps, consumes 15\% [37]. The proportion of energy use from different stages of the CAS treatment system are presented in Fig. 2 [38]. Compared with the CAS system, oxidation ditch (OD) treatment systems have higher energy demands of 0.5-1.0 (Australia), 0.302 (China), or $0.43-2.07 \mathrm{kWh} / \mathrm{m}^{3}$ (Japan) because of longer hydraulic retention time (HRT) and higher energy consumption for higher specific-oxygen demand [31, 39, 40].
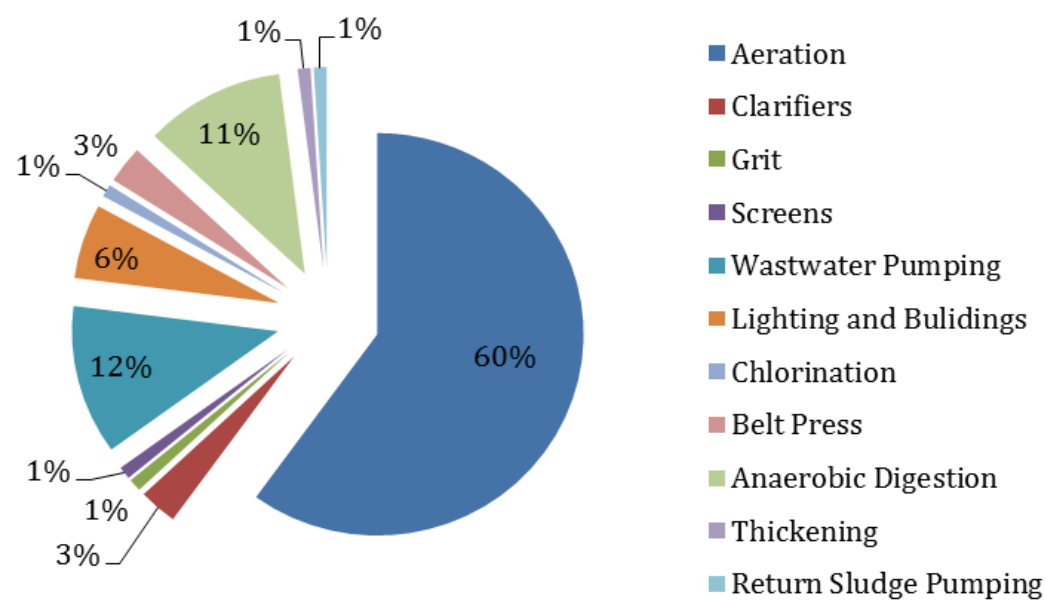
Fig. 2. The proportion of energy use associated with different components of a CAS treatment system. Data obtained from [38].

Yang et al.[40] found that the average energy consumption of WWTPs with different secondary treatment technologies in China in 2006 (Fig. 3) were as follows: 0.340 $\mathrm{kWh} / \mathrm{m}^{3}$ for $13 \mathrm{WWTPs}$ with extended aeration systems, $0.336 \mathrm{kWh} / \mathrm{m}^{3}$ for 103 WWTPs with sequencing batch reactors (SBR), $0.330 \mathrm{kWh} / \mathrm{m}^{3}$ for $36 \mathrm{WWTPs}$ with biomembrane systems, $0.302 \mathrm{kWh} / \mathrm{m}^{3}$ for 170 WWTPs with OD systems, 0.283 $\mathrm{kWh} / \mathrm{m}^{3}$ for 48 WWTPs with anoxic-oxic systems (A/O), $0.269 \mathrm{kWh} / \mathrm{m}^{3}$ for 36 WWTPs with CAS systems, $0.267 \mathrm{kWh} / \mathrm{m}^{3}$ for 87 WWTPs with anaerobic-anoxic-oxic systems (A/A/O), $0.253 \mathrm{kWh} / \mathrm{m}^{3}$ for $10 \mathrm{WWTPs}$ with land treatment and constructed wetlands, and $0.219 \mathrm{kWh} / \mathrm{m}^{3}$ for 17 WWTPs with adsorption-biology systems. WWTP configuration also influences the energy consumption in WWTPs with similar treatment technologies. For example, the membrane bioreactor (MBR) treatment system shows relatively large ranges of energy consumption from $0.37 \mathrm{kWh} / \mathrm{m}^{3}$ (an optimized MBR unit in the Ulu Pandan WWTP in Singapore) [41] to $0.7-1.6 \mathrm{kWh} / \mathrm{m}^{3}$ [41-43] or even higher values of 2.2-2.5 $\mathrm{kWh} / \mathrm{m}^{3}[42,44,45]$. Further research has shown that MBR units consume range from 55\%-90\% of total energy consumption, depending on the additional treatment processes [46]. An advanced membrane bioelectrochemical reactor (MBER) with hollow-fiber membranes installed, theoretically consumes $0.09 \mathrm{kWh} / \mathrm{m}^{3}$, which is significantly lower than the energy consumption of more standard MBRs [47]. 


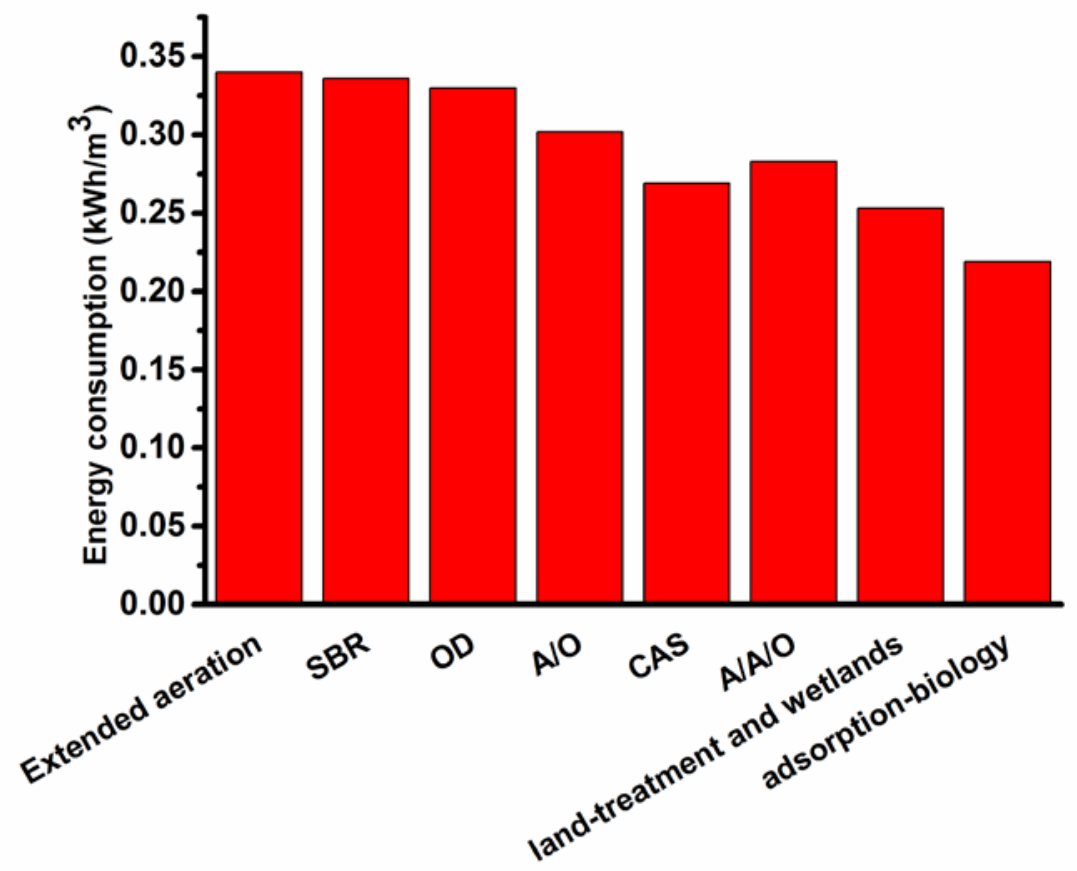

Fig. 3. Energy consumption of secondary treatment plants with different treatment technologies in China. Data obtained from [40].

Advanced wastewater treatment processes are highly energy-intensive because of the nutrient removal processes involved; these processes have been shown to require 0.39-3.74 $\mathrm{kWh} / \mathrm{m}^{3}$ of energy in Japan, whereas in municipal WWTPs in the USA these processes typically consume $0.43 \mathrm{kWh} / \mathrm{m}^{3}$, which is similar to the energy consumption of these processes in Taiwan $\left(0.41 \mathrm{kWh} / \mathrm{m}^{3}\right)$, New Zealand $(0.49$ $\left.\mathrm{kWh} / \mathrm{m}^{3}\right)$, and Hungary $\left(0.45-0.75 \mathrm{kWh} / \mathrm{m}^{3}\right)$ [31, 32, 34, 39]. According to the Water Environment Federation, in advanced water treatment processes, dual-media filters account for $13 \%$ of energy consumption on average [48]. Schnoor[49] pointed out that the greatest story in water history during the 21st century is probably the significant energy input in the treatment of wastewater through membranes and reverse osmosis (RO) for drinking water supplies. Although RO membrane processes are effective in advanced wastewater treatment, they are very energy intensive. Research from Spain and Saudi Arabia, has shown that RO consumes 0.8 and 1.6 $\mathrm{kWh} / \mathrm{m}^{3}$, respectively [50]. 
Sludge treatment is a very energy-intensive process in WWTPs. Research focusing on 10 WWTPs in Greece, with 15,000-4,000,000 population equivalents (PE), indicated that sludge treatment sections were significant energy consumers, accounting for about $8 \%$ of the total energy consumption of these WWTPs [37]. The Ringsend WWTP in Ireland, which provides advanced treatment for 1.7 million PE, uses Cambi thermal hydrolysis anaerobic digestion (AD) to treat sludge and consumes approximately 0.26 MWh/ton of processed dry sludge [22]. In France, Denmark, Germany and Belgium, over 14\% of sewage sludge is incinerated; whereas in the USA and Japan, the proportion of incinerated sewage sludge is $25 \%$ and over $50 \%$, respectively [51]. An analysis of 985 Japanese municipal WWTPs concluded that the specific energy consumption of the CAS method with incineration for sludge treatment is $0.38-1.49 \mathrm{kWh} / \mathrm{m}^{3}$, which is substantially higher than that of CAS method without incineration $\left(0.39-3.74 \mathrm{kWh} / \mathrm{m}^{3}\right)$ [39].

\subsection{Energy consumption of WWTPs with different sizes}

The size of WWTPs (population equivalent, organic, or hydraulic load) also exerts significant effect on energy consumption. A survey characterizing approximately 15,000 publicly owned wastewater treatment facilities (POTWs) currently in operation in the USA reported that unit electricity requirements for trickling filter system, activated sludge, advanced wastewater treatment without nitrification, and advanced wastewater treatment with nitrification are $955\left(0.252 \mathrm{kWh} / \mathrm{m}^{3}\right), 1,322$ $\left(0.349 \mathrm{kWh} / \mathrm{m}^{3}\right), 1,541\left(0.407 \mathrm{kWh} / \mathrm{m}^{3}\right)$, and $1,911 \mathrm{kWh} /$ million gallons $(0.505$ $\mathrm{kWh} / \mathrm{m}^{3}$ ) on average, respectively [52]. The variations in electricity consumption with size in these POTWs are shown in Fig. 4. The unit electricity consumption of all these four processes decreases with increasing plant size. 


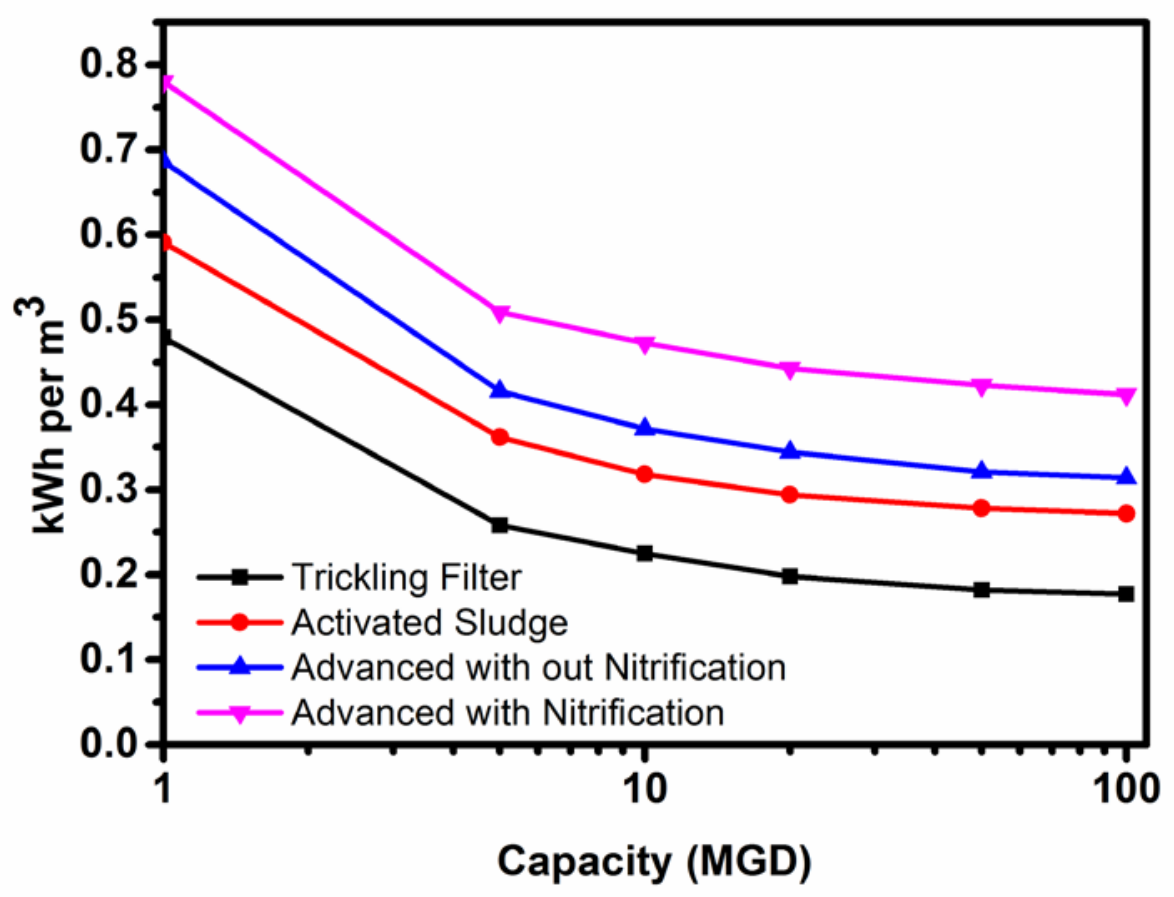

Fig. 4. Variation of electricity consumption with different sizes of WWTP for representative wastewater treatment processes. Data is taken from 1500 POTWs in USA [52]. Note: MGD denotes million gallons per day.

The same trend is also observed in Japan and China. Fig. 5a and 5b show the relationship between energy input and size of WWTP for OD and CAS methods in WWTPs in Japan [39]. For the OD method, the inflow volume ranges from $100 \mathrm{~m}^{3} / \mathrm{d}$ to $8,500 \mathrm{~m}^{3} / \mathrm{d}$, whereas the corresponding energy consumption decreases from 2.07 $\mathrm{kWh} / \mathrm{m}^{3}$ to $0.44 \mathrm{kWh} / \mathrm{m}^{3}$. For the CAS method without incineration, the inflow volume increases from $600 \mathrm{~m}^{3} / \mathrm{d}$ to $283,000 \mathrm{~m}^{3} / \mathrm{d}$, with a corresponding energy consumption in the range of $1.89-0.30 \mathrm{kWh} / \mathrm{m}^{3}$. The energy consumption in Fig. $5 \mathrm{~b}$ shows a similar trend for advanced wastewater treatment systems. The number of WWTPs of different sizes in China in 2009 is shown in Fig. 5c [53]. Most of these WWTPs are operated with an inflow of about $5 \times 10^{4} \mathrm{~m}^{3} / \mathrm{d}$. Fig. $5 \mathrm{~d}$ shows that the unit energy consumption in these WWTPs decreases exponentially with increasing inflow [53]. Similar results have been found in Slovakia, where according to the statistical 
data of energy intensity of 68 municipal treatment plants from 2011, large WWTPs are more energy efficient than small ones. The WWTPs with daily inflow above 5000 $\mathrm{m}^{3} /$ day have a relatively constant energy demand of $0.331-0.414 \mathrm{kWh} / \mathrm{m}^{3}$ [32]. All these results indicate that unit energy consumption in WWTPs decreases with increasing wastewater inflow. Equipment and devices operating in WWTPs can work with high efficiency with increasing wastewater and pollutant concentration; accordingly, the treatment condition is relatively stable. Moreover, small plants may not employ as well-trained staff as large ones, thereby causing a significant difference in management levels. Nevertheless, some studies have suggested that small WWTPs can reach the same or higher energy efficiency as larger ones [54]. For example, in a study from Austria, Soban'tka et al.[55] showed that plants between 22,000 PE and 49,700 PE can attain similar energy and cost efficiency as large plants with 95,000-950,000 PE. Their study was based on both the nitrogen budgets of extended statistical entropy analysis and service population, which may explain its different result from most studies based on nitrogen removal rate.
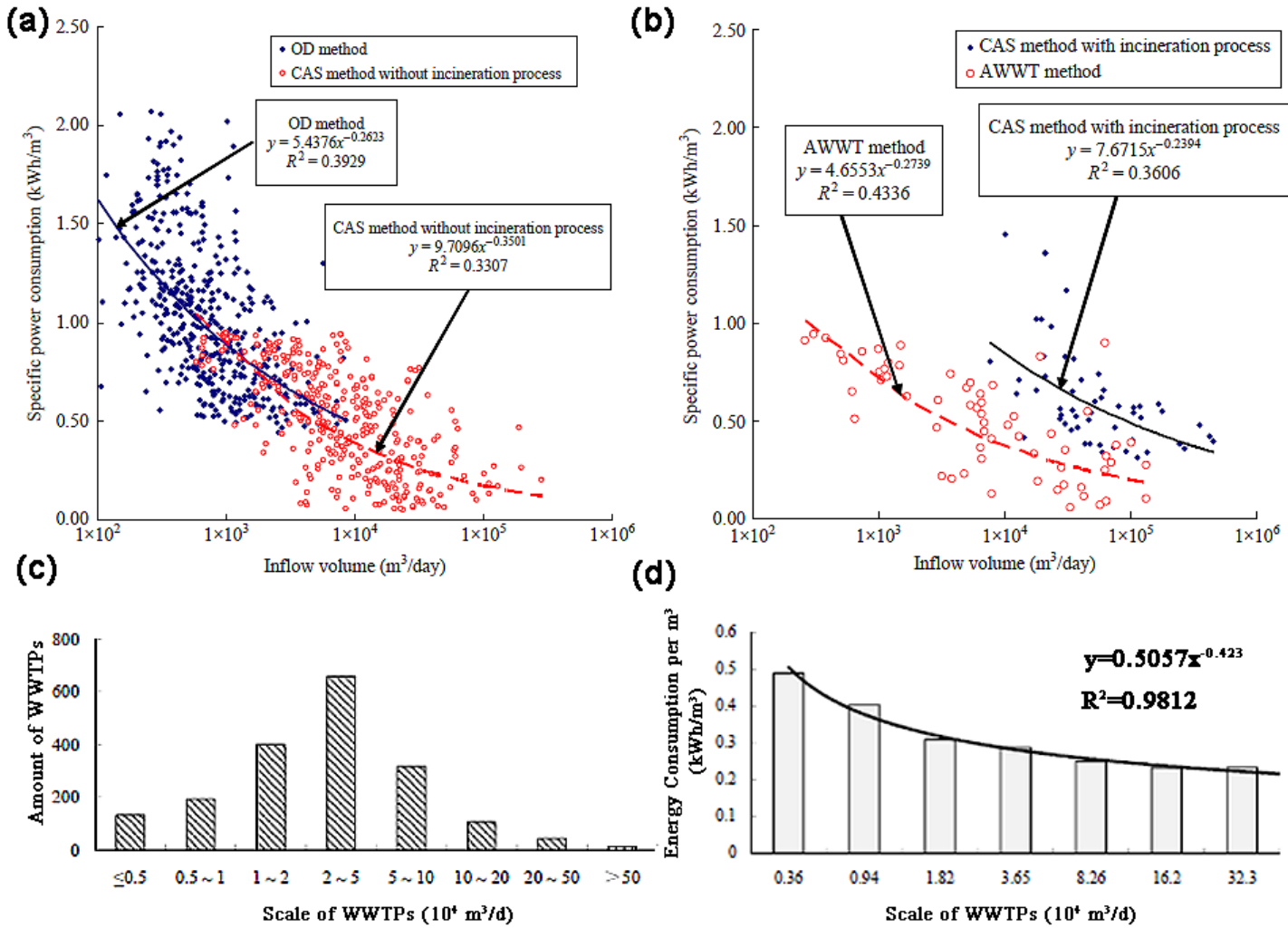

Fig. 5. The relationship between energy consumption and inflow volume of (a) OD and 
CAS treatment systems without incineration process and (b) CAS treatment systems containing incineration process and advanced wastewater treatment in Japan. Note: AWWT denotes advanced wastewater treatment. Adapted from [39]. (c) Number of wastewater treatment plants (WWTPs) of different sizes in China. (d) Energy consumption with respect to scale of WWTP in China. Adapted from [53].

To date, the selection of WWTP size or whether small WWTPs should be merged into a larger plant is considered for construction of centralized and decentralized wastewater treatment systems [56-59]. Energy efficiency and operating cost are the key factors influencing the whether wastewater treatment plants should be centralized or decentralized. A case study in California comparing a decentralized and centralized wastewater treatment system based on a life cycle assessment (LCA) showed that the decentralized wastewater treatment system consumes approximately 37,000 J of energy per liter of wastewater, while the centralized system uses only approximately $6,800 \mathrm{~J}$ for treating the same amount of wastewater [60]. As shown in Fig 6, the system-wide LCA comparison of these two wastewater systems shows that in each of the four phases of their life cycle ((A) material manufacture and supply for the WWTPs construction, (B) material transportation, (C) onsite equipment/vehicle use and (D) the direct and upstream energy use), the unit energy intensity of the decentralized WWTP treating 20 million liters per year was higher than the centralized one treating 92,000 million liters per year.[60] This is because of the scale effect where the centralized WWTP can work with higher efficiency. The operational electricity is the aspect of the LCA with the greatest energy intensity in the decentralized system compared to the centralized system. In addition, the specific decentralized WWTP studied has additional energy requirements for the pumping of the discharge of the treated water into the holding tank. In conclusion, centralized WWTPs reduce energy consumption and environmental impact on a per volume basis over decentralized systems largely because of the scale effect; however, the latter may be more competitive when considering water reuse, specifically when the local water source is seawater desalination [60, 61]. 


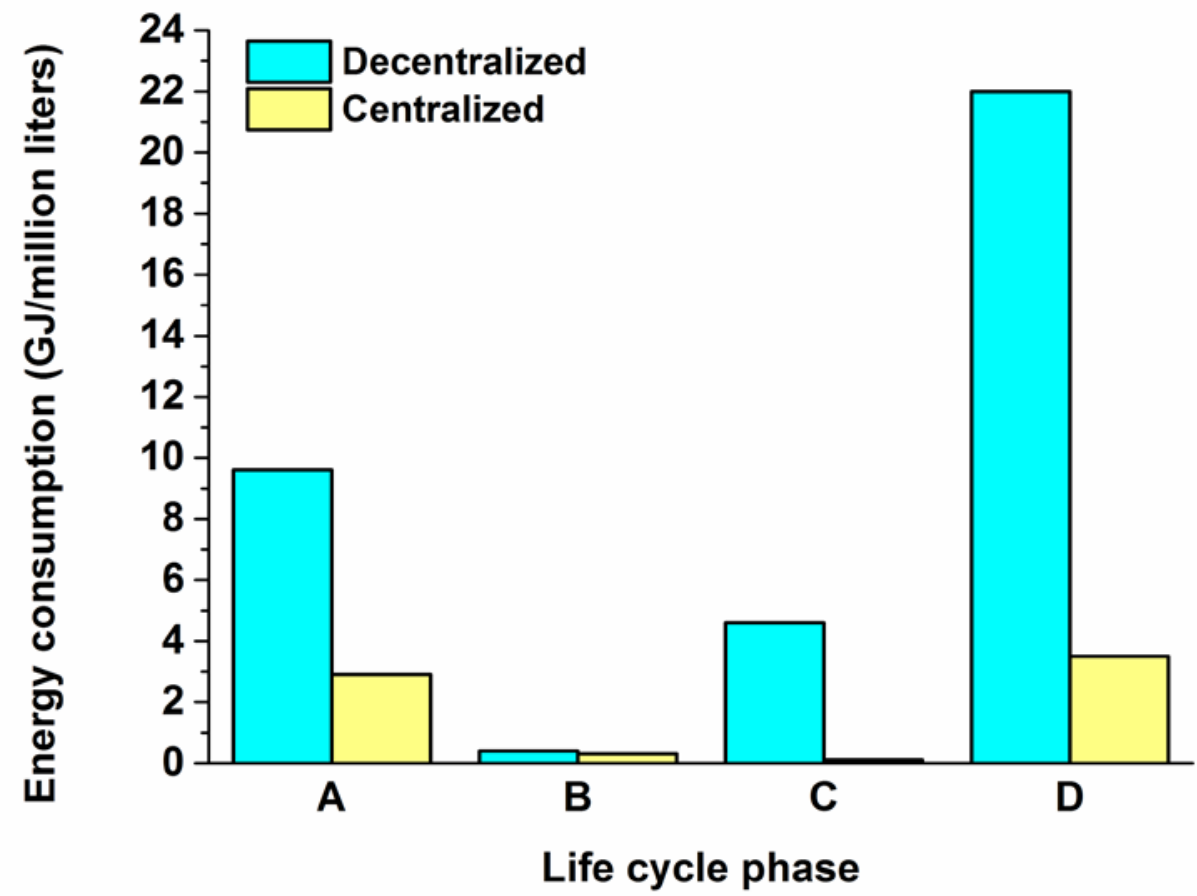

Fig. 6. Case study of lifecycle energy use for a centralized and decentralized WWTP in California. Data source: [60]. Phase A: Material manufacture and supply for the WWTP's construction. Phase B: Material transportation. Phase C: Onsite equipment/vehicle use. Phase D: Direct and upstream energy use.

\subsection{Energy consumption of WWTPs in different regions}

The benchmark energy consumption of WWTPs in different regions is also investigated in this paper. For example, WWTPs in Sweden consume approximately 45\% more electricity than Austrian WWTPs, therefore there is a higher potential for energy saving in Swedish WWTPs [62]. The main reason for such differences in energy consumption between Sweden and Austria is that benchmarking studies have been conducted in Austria for many years to underpin improvements in energy efficiency. Repeated energy benchmarks since 1990's have shown a decrease of 30\% in energy consumption in WWTPs in Austria through improvements [62]. However, a benchmark energy consumption in WWTPs has only successfully been developed and used in some developed countries over the last two decades and is rarely obtained in other countries. In addition, the current situation of energy consumption in WWTPs at 
international level is still to be determined. Particularly, the causes of energy differences among WWTPs across countries is unclear [63]. The energy intensity and the proportion of national energy consumption associated with WWTPs in different countries are shown in Table 1.

Table 1. Energy intensity and the proportion of national energy consumption associated with WWTPs in different countries

\begin{tabular}{cccc}
\hline $\begin{array}{c}\text { Regions/ } \\
\text { Countries }\end{array}$ & $\begin{array}{c}\text { Energy intensity (kWh per } \\
\mathrm{m}^{3} \text { wastewater treated) }\end{array}$ & $\begin{array}{c}\text { Proportion of energy consumption } \\
\text { in national level (\%) }\end{array}$ & Reference \\
\hline USA & 0.52 & 0.6 & {$[63]^{\mathrm{a}}$} \\
China & 0.31 & 0.25 & {$[63]^{\mathrm{b}}$} \\
Germany & $0.40-0.43$ & 0.7 & {$[63]^{\mathrm{c}}$} \\
South Africa & $0.079-0.41$ & - & {$[63]$} \\
Japan & $0.304^{\mathrm{d}}$ & - & {$[40]$} \\
Korea & 0.243 & 0.5 & {$[64]$} \\
Sweden & 0.42 & 1 & {$[65]$} \\
Switzerland & 0.52 & - & {$[66]$} \\
Spain & 0.53 & - & {$[66]$} \\
Israel & - & 10 & {$[64]$} \\
\hline
\end{tabular}

Note:

${ }^{\mathrm{a}}$ This date is from 2008

${ }^{\mathrm{b}}$ This date is from 2008

${ }^{\mathrm{c}}$ This date is from 2008

${ }^{\mathrm{d}}$ This value includes effluent disinfection and sludge digestion

The USA is a typical developed country and has a unit electricity consumption of $0.52 \mathrm{kWh} / \mathrm{m}^{3}$ for WWTPs. The electricity consumption of wastewater treatment in the USA is approximately $0.6 \%$ of the annual electricity consumption.[63] Compared with the USA, Asian countries show lower energy intensity for wastewater treatment (0.31, 0.304, and $0.243 \mathrm{kWh} / \mathrm{m}^{3}$ for China, Japan, and Korea, respectively).[40, 63, 64] Among these three Asian countries, China has the highest energy intensity and a lower proportion of national energy use associated with WWTP compared with the 
USA (only 0.25\%).[63] The relatively low proportion of national energy use by WWTPs in China is due to a high total national energy consumption and a relatively low rate of wastewater treatment, especially in rural areas and small towns. In addition, the energy consumption of WWTPs is strongly related to the treatment levels adopted. Generally, a low percentage of national energy consumption associated with WWTP means inadequate wastewater treatment in the country as a whole. Currently, there are still gaps in the monitoring and treatment of wastewater in China. However, recent more stringent regulations relating to effluent discharge are prompting more adequate treatment facilities and strategies in China.

The differences in energy intensity and percentage of national energy consumption are affected by the different target effluent quality and strategies in different countries. For example, electricity intensity of WWTPs in South Africa varies between 0.079-0.41 kWh/m $\mathrm{m}^{3}$. In South Africa, the most widely used technologies are that of lagoon and trickling filters, which are low energy intensity strategies [63]. In European countries, the energy intensity of $0.42-0.53 \mathrm{kWh} / \mathrm{m}^{3}$ for wastewater treatment is similar among Sweden, Germany, Switzerland, and Spain, with proportions of national energy consumption from WWTP ranging from 0.7 to $1 \%$ [63, 66]. Advanced treatment techniques are widely used in these European countries to obtain high quality effluent. In contrast, the proportion of national energy consumption in Israel is $10 \%$, which is considerably higher than that of other countries. This large difference may be attributed to the great amount of wastewater treated for reuse in Israel due to the serious water shortage problem [65].

In addition, the difference in the results between countries may also result from different statistical methods and scopes in determining energy intensity. For example, in developed countries the energy consumption associated with sludge treatment is usually included in energy benchmark, in contrast to some developing countries such as China, where this is usually not included. In China, although most WWTPs have sludge treatment facilities, many WWTPs did not include the energy input for sludge treatment and disposal. Many WWTPs reported that the sludge was transferred to a third party for disposal without information on energy consumption. Others simply 
declared that sludge was dewatered without further information about the final disposal and energy statistics in this section [67]. Thus, the separate management system of sludge and sewage treatment suggests that energy consumption associated with sludge treatment is usually not included in the energy benchmark in China. This lack of inclusion of some aspects of the WWTP process in China likely accounts in part for the relatively low percentage energy consumption associated with WWTP in China.

\section{The feasibility and challenges of energy self-sufficient WWTPs}

The energy requirements associated with WWTP is likely to grow, with population growth and increased regulatory control of water quality discharge standards. A study in southern California, USA has shown that the energy consumed by WWTPs accounts for about $20 \%$ of the municipality's total energy use. However, it is predicted that in the USA this proportion will further increase by 20\% in the next 15 years because of the growth in contaminant load caused by population growth and increasingly strict regulatory and related environmental protection laws and standards for water quality and reclaimed water $[68,69]$. Due to increasing energy costs and concerns about the environment, the potential for energy self-sufficient WWTPs has become an area of increasing research and innovation. Energy self-sufficient WWTPs and carbon-neutral (zero greenhouse gas emissions) WWTPs are different, although carbon neutrality is often referred by its narrow definition: energy neutrality [70]. Energy self-sufficient WWTPs commonly refer to WWTPs generating $100 \%$ or more of their energy requirement for operation solely from the energy embedded in the water and wastes they treat with zero external energy supply [71]. Two complimentary aspects are required to realize energy self-sufficiency in WWTPs: (1) Energy savings via improving efficiency in unit processes. Most wastewater treatment facilities have the potential to reduce their energy input by $30 \%$ or more through energy efficiency improving measures and treatment process modifications [68]. (2) The recovery of energy from renewable and/or unused energy sources available in WWTPs such as chemical energy, heat energy and etc. In this section, possible routes 
and recent advances to realize energy self-sufficiency in WWTPs are summarized and discussed in detail.

\subsection{Energy production from WWTPs}

\subsubsection{Chemical energy recovery and related technologies}

Biogas and combined heat and power (CHP). Wastewater is commonly considered a potential energy source [26, 72, 73]. The potential energy production associated with wastewater is great because it contains a wealth of organic matter and carbon energy. A large amount of energy is easily extracted when the load of organic matter in influent wastewater is high. The main energy source in a WWTP is the biogas produced in digester. The use of biogas for digester heating and electricity generation is a sustainable way of recovering energy from WWTPs with subsequent sludge reduction [15, 74]. An energy balance analysis of five WWTPS in Catalonia, Spain showed that $67 \%$ of the energy in raw wastewater was transferred to the sludge and subsequent anaerobic digestion of the sludge can recover $52 \%$ of this energy by transforming it into biogas [75]. This biogas can then be used for heating and electrictiy generation. A typical biogas composition from digested sludge includes about $50 \%-70 \%$ of $\mathrm{CH}_{4}$ and $30 \%-50 \%$ of $\mathrm{CO}_{2}$ [76]. Compared with WWTPs without sludge digestion, WWTPs with and sludge digestion consume $40 \%$ less net energy on average [4]. Combined Heat and Power (CHP) technologies generate both electricity and heat from a single fuel source at the same time. CHP systems using the anaerobic digestion of sludge is the technology most adopted in the existing energy self-sufficient WWTPs, such as in Strass (Austria) [77], Steinhof (Germany) [78], and Sheboygan (America) [79]. In the USA, wastewater treatment CHP systems are present in 133 sites and, as of June 2011, represent 437 MW of capacity [80]. In the Netherlands, sludge digestion is already widely used by many wastewater treatment facilities producing 95 million $\mathrm{Nm}^{3}$ of biogas with a potential energy value of 2,215 TJ [72].

The optimization of AD can be the key towards energy self-sufficient wastewater treatment plants [30]. It was found that anaerobic MBR (AnMBR) technology could 
produce more net energy as biogas than CAS with anaerobic digestion based on life cycle comparison [81]. While through coagulation, flocculation and microsieving membrane processes to maximise the extraction of organic matter into the sludge can also increase the energy recovery through AD compared with CAS [82]. Besides different treatment processes, $\mathrm{AD}$ is also influenced by sludge-specific loading rate, sludge retention time (SRT) and organic loading rate. A study on a high-rate contact stabilization reactor system showed that the system operated at high sludge-specific loading rates and lower SRT can recover more energy. The highest energy recovery was achieved at a contact to stabilization time ratio of 0.14 , with $36 \%$ of the raw energy in wastewater recovered as methane [83]. Short sludge ages also enable more energy recovery in high-rate SBR processes as the anaerobic degradability extent of the sludge was $85 \%$ for 2 days, $73 \%$ for 3 days and $63 \%$ for 4 days [84]. In a mesophilic AnMBR combined with a heat pump and forward osmosis (FO) wastewater treatment project, high methane production over $300 \mathrm{ml} / \mathrm{g}$ COD (equivalent energy: $1.57 \mathrm{kWh} / \mathrm{m}^{3}$ from wastewater with $500 \mathrm{mg} / \mathrm{L}$ COD) can obtained at high sludge organic loading rate [85]. Thermal pre-treatment of sludge can improve the AD performance of sludge. A case study from the largest Italian WWTP showed that the sludge when thermally pre-treated produced $21 \%$ and $31 \%$ more methane by $\mathrm{AD}$ than untreated sludge at 70 and $90{ }^{\circ} \mathrm{C}$ for $3 \mathrm{~h}$, respectively [86]. Another recent hypothetical study of a WWTP showed that $585 \mathrm{~kW}$ of energy could be saved by thermal pre-treatment of $3.5 \%$ of sludge at $80{ }^{\circ} \mathrm{C}$ for $0.5 \mathrm{~h}$ [87]. Among the total energy saved, $159 \mathrm{~kW}$ energy was produced from the increase in biogas generated, and $334 \mathrm{~kW}$ and $82 \mathrm{~kW}$ was saved in the pumping and mixing sludge system respectively [87].

Many WWTPs mix kitchen wastes with sludge for anaerobic coprocessing. This treatment prepares the substrates, improves organic load, increases biogas yield and energy recovery [88]. Co-digestion with food waste also accelerates methane production rates with higher hydrolysis rates compared with mono-digestion [89]. Additionally, co-digestion with lignocellulose from maize or grass in rural areas or urban biomass also can contribute to energy production in municipal WWTPs. A 
geographic information system (GIS) analysis of the green areas of the Rhine-Ruhr metropolitan area showed the potential for these areas to provide enough biomass for co-digestion, to cover $67 \%$ of the energy demand of 12 typical WWTPs in the city [90].

Anaerobic ammonium oxidation (anammox). For traditional aerobic activated sludge, such as $\mathrm{A}^{2} / \mathrm{O}$, some WWTPs add organic carbon material in wastewater during the nitrogen and phosphorus removal process to ensure normal microbial growth, thereby creating a difficulty in achieving energy independence. Anammox is a good choice for nitrogen removal to ensure that sufficient amount of organic matter remains; anammox includes SHARON ${ }^{\circledR}$ (single rector for high activity ammonia removal over nitrite), $\mathrm{CANON}^{\circledR}$ (completely autotrophic nitrogen removal over nitrite), OLAND ${ }^{\circledR}$ (oxygen-limited autotrophic nitrification and denitrification), DEAMOX $^{\circledR} \quad$ (denitrifying ammonium oxidation), DEMON $^{\circledR} \quad$ (aerobic deammonification), and other related technologies. ANAMMOX bacteria use $\mathrm{NO}_{2}-\mathrm{N}$ as electron acceptors to oxidize $\mathrm{NH}_{4}{ }^{+}-\mathrm{N}$ and obtain nitrogen directly under anaerobic or anoxic conditions (Fig. 7) [91]. Compared with traditional nitrification/denitrification, anammox decreases the aeration rates and reclaims the maximum organics from the water hence improving energy efficiency [92]. Energy-efficient total ammonia nitrogen removal can also be realized via partial anammox technology [93]. The current partial nitrification/anammox (PN/A) installations are mainly in Europe; although increasing side-stream treatment implementation, including the moving bed biofilm reactor [94], SBR [95], and granular sludge processes [96] also occur in North America [93]. PN/A can also save energy by reducing oxygen demand for nitrification and producing less excess sludge [97]. A laboratory-scale study on a membrane combined process of a submerged AnMBR and CANON MBR with two major 4L-containers (one was used as AnMBR, the other one was used as CANON MBR) for treating municipal wastewater under ambient temperatures $\left(23 \pm 3^{\circ} \mathrm{C}\right)$. The study showed that the membrane process with combined $\mathrm{AD}$ and nitritation-anammox could effectively remove COD(96.70\%) and nitrogen (81.40\%) [98]. The net energy input was only $0.09 \mathrm{kWh} / \mathrm{m}^{3}$ with $70 \%$ energy 
self-sufficiency, showing much greater energy efficiencies compared with conventional MBRs $\left(1.11 \mathrm{kWh} / \mathrm{m}^{3}\right)$ [98]. These combined processes might present promising treatment technologies for the real applications of energy self-sufficient WWTPs construction. A hybrid, floc-based sequential partial nitritation and anammox for nitrogen removal without external carbon addition (called new activated sludge) achieves 33\% decrease in electricity consumption for aeration and 50\% decrease in sludge production compared with conventional nitrification/denitrification [99]. Gao found that the energy in anammox reactors can be recovered through a combination of direct anaerobic treatment and autotrophic nitrogen removal at moderately low temperatures [100]. This technology makes it possible for municipal WWTPs to become energy self-sufficient or energy-producing systems [101]. However, anammox also presents some drawbacks, including the long growth time of anammox bacteria and difficult cultivation; therefore, this technique is rarely used in full-scale WWTPs [102].

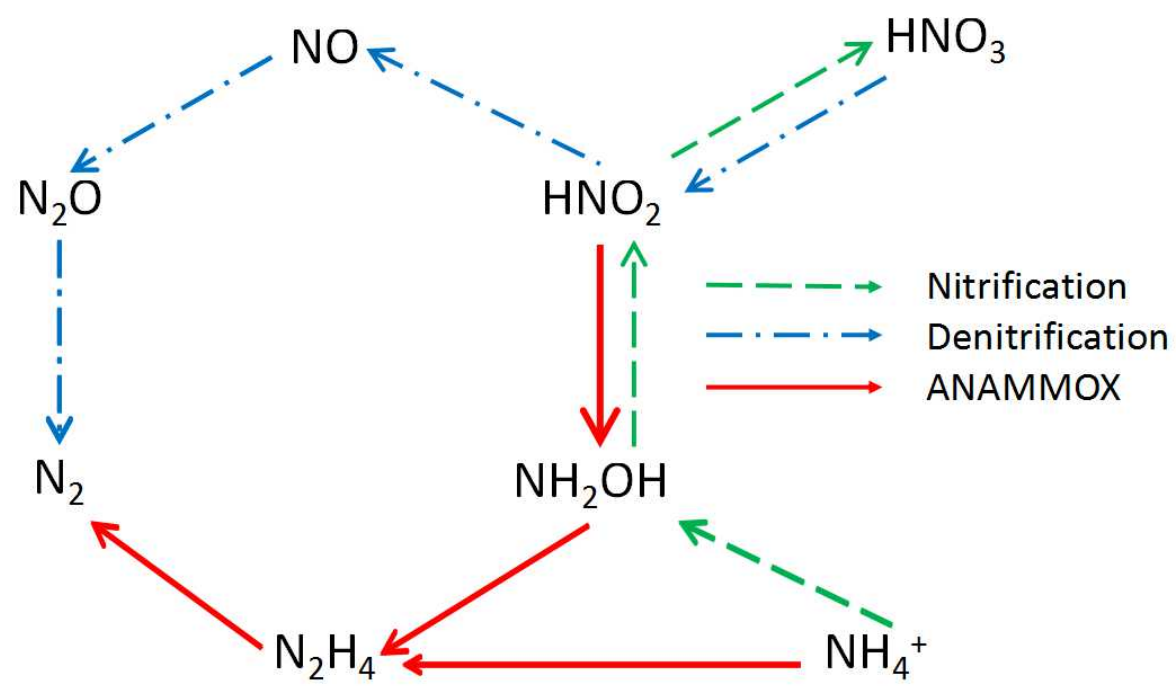

Fig. 7. Nitrogen cycling network of nitrification, denitrification, and anaerobic ammonium oxidation

Microbial fuel cell (MFC). Power generation using MFC is observed in several WWTPs, including both domestic and industrial wastewater treatment [103-110]. MFC technology can transform the chemical energy of excess sludge into electrical energy [106]. Unlike conventional AD, MFC generates electricity directly, which is a 
considerable potential advantage because biogas combustion and conversion into electricity results in low yield, wasting up to $70 \%$ of the energy contained in biogas [111]. In theory, when the coulombic efficiency (the fraction of electron charge that contributes to electricity generation) is $40 \%$ [112] and the HRT of domestic wastewater treatment is $20 \mathrm{~h}$, the potential energy that can be recovered from wastewater using MFC can reach $0.65 \mathrm{kWh} / \mathrm{m}^{3}$ [113]. This calculation shows that MFCs exhibit the potential to achieve energy sufficiency across the whole wastewater treatment process, as energy consumption ranges between 0.3 and $0.6 \mathrm{kWh} / \mathrm{m}^{3}$ using CAS technologies [31]. In addition, MFCs also act as energy-saving technologies which can reduce aeration (for air-breathing cathode MFCs) and produce less sludge than CAS [114-116]. In order to promote large-scale application of MFCs, a large stackable horizontal MFC system with 250 L modules has been designed for real sewage treatment [117]. Studies on this system show that the MFC system can produce a high stable current of $0.435 \mathrm{~A}$ in each module and a maximum energy output of $116 \mathrm{Mw}$ [117]. Another 90 L stackable baffled MFC system with five modules was designed for treating wastewater from a brew house and successfully operated without energy input for 6 months. This system produced enough energy $\left(0.153 \mathrm{KWh} / \mathrm{m}^{3}\right)$ for the operation of the whole system, resulting in the recovery of $0.055 \mathrm{KWh} / \mathrm{m}^{3}$ of net energy [118]. High strength wastewater also can be treated accompanying with energy generation by MFCs. A study showed that high strength wastewater (COD: $9970 \mathrm{mg} / \mathrm{L}$ ) could be used as a feedstock to generate energy by an air-cathode MFC with membrane-electrode assembly system [109]. In this system an electricity density achieved a maximum value of $5.06 \mathrm{~W} / \mathrm{m}^{3}$ after 14 days of operation [109]. A new MFCs system based on ionic liquid membranes was investigated for use with high COD content industrial wastewater treatment, resulting in the generation of $32 \mathrm{~mW} / \mathrm{m}^{3}$ power generation [119]. Sludge can also be used as a feedstock for energy generation from MFCs. Recent research on an up-flow constructed wetland-MFC showed that the macrophytes E. nuttallii combined with appropriate supplementary aeration could increase the bioelectricity generation as $\mathrm{O}_{2}$ was used as a terminal electron acceptor for electrical current generation in the MFC [120]. A combined 
system of MBR and MFC has also been studied and more than $430 \mathrm{mV}$ of electricity voltage output produced from a single sludge-MFC.[121]

However, MFC may not be sufficient to achieve high treatment efficiency as a stand-alone treatment technology [122]. Recent advances in improving energy performance of MFCs mainly focus on the combination of MFC with membrane treatment processes. Compared with conventional air-cathode MFCs, an electrochemical membrane bioreactor using graphite felt as the cathode had higher treatment efficiency with similar energy production [123]. Thus, this system can reduce total energy consumption as no further treatment is needed. If this strategy can be adopted by a WWTP with a capacity of 50,000 $\mathrm{m}^{3} / \mathrm{d}$, net electricity of about 3850 kWh could be generated per day [123]. An AnMBR system developed with microfiltration membranes serving as the cathodic chamber of a MFC can produce stable electricity $(0.132 \mathrm{~V})$ over $600 \mathrm{~h}$ of operation time [124]. In a novel overflow type electrochemical MBR the MFC showed an efficient power production density of $629 \mathrm{~mW} / \mathrm{m}^{3}$ and a high voltage output at an appropriate range of HRT (8.5-16.9 h) [125]. Studies of a wastewater treatment system with microbial osmotic fuel cells using FO membrane as a barrier between the cathode and anode units showed a higher electricity production $\left(43 \mathrm{~W} / \mathrm{m}^{3}\right)$ than MFCs with anion exchange membranes (40 $\mathrm{W} / \mathrm{m}^{3}$ ) or cation exchange membranes $\left(23 \mathrm{~W} / \mathrm{m}^{3}\right)$ [126]. It was also found that the electricity production from MFCs can be increased from $3 \mathrm{~W} / \mathrm{m}^{3}$ up to $11.5 \mathrm{~W} / \mathrm{m}^{3}$ with the increased conductivity and buffering capacity from integrating MFCs and osmotic membrane bioreactors [127]. Another laboratory scale study showed that a two-stage wastewater treatment system consisting of MFCs and an anaerobic fluidized bed MBR operated for 50 days can achieve energy indecency with 0.0197 $\mathrm{kWh} / \mathrm{m}^{3}$ of energy produced by the MFCs and $0.0186 \mathrm{kWh} / \mathrm{m}^{3}$ of total energy required for system operation [128]. Another wastewater treatment system consisting of MFCs and a fluidized bed MBR was developed for the treatment of actual wastewater from a cheese factory and this system also successfully operated in an energy self-sufficient manner [129]. In a case study with combined MFC and intermittently aerated biological filter system, the electrical energy produced by the 
MFC $\left(0.27 \mathrm{kWh} / \mathrm{m}^{3}\right)$ is successfully used to power the pumping $\left(0.014 \mathrm{kWh} / \mathrm{m}^{3}\right)$ and aeration systems $\left(0.22 \mathrm{kWh} / \mathrm{m}^{3}\right)$ [130]. Hence, the incorporation of a MFC can make wastewater treatment a zero-energy-input process, and good treatment performance can be achieved in a MFC-based combined system. However, electrode materials in MFC are expensive for wastewater treatment and therefore are limited to specific applications of MFCs.[113]

Algal-based wastewater treatment and biofuel production. Algal-based treatment systems use natural biological wastewater treatment processes based on the microalgae. These systems can be used to treat the wastewater from small-sized communities at low cost [131]. However, a large land area is usually needed for algal-based wastewater treatment [132]. Compared with conventional wastewater treatment technologies, the algal-based treatment systems can save over $50 \%$ of energy usage due to algal photosynthesis [132]. In addition, the by-product of algal-based wastewater treatment has great potential for biofuel production. It was reported that 800-1400 GJ/ha/year energy can be produced from this system [133]. In Brazil, if 40\% of wastewater from municipalities in 2012 was treated by algal-based wastewater treatment system, the total national biodiesel production would increase by $21.4 \%$, with $2.98 \times 10^{6} \mathrm{~m}^{3}$ of biodiesel produced through these means [134]. However, the energy production in algal-based wastewater treatment system is affected by various factors such as light, temperature, $\mathrm{CO}_{2}$ availability, $\mathrm{HRT}$, mixing, cultivation mode, algal recycling, nutrients, invertebrates in the system and algal biofuel options [133]. Thus, optimizing these conditions is important. A study of a high rate algal pond (HRAP) in New Zealand showed that the performance of HRAP can be enhanced by adding $\mathrm{CO}_{2}$ [135]. It was also suggested that converting the biomass produced in HRAP to biofuel through hydrothermal liquefaction processes could achieve the highest conversion efficiency (>70\%) compared with other conversion pathways like pyrolysis, AD or gasification [133]. Another study showed that the energy recovery by converting the biomass in the algal-based treatment system into bio-crude oil through hydrothermal liquefaction process could achieve 82-88\% of the energy content of the original feedstock [136]. 


\subsubsection{Other energy recovery techniques}

Another important energy source contained in wastewater is the heat energy present $[25,137]$. This energy can be used for the heating of neighboring residences or added to the district heating system through heat exchangers and heat pumps. In addition, the lower temperatures of effluent water will reduce the impact on the aquatic environment. For example, a study of a WWTP in China showed that, at least 50\% of energy consumption from the plant could be recovered from thermal energy of the effluent; completely offsetting the energy deficit because of insufficient energy converted from excess sludge [138]. The heat energy produced from the treatment processes is higher than the required heating energy in the plant. The heat energy recovered from wastewater can be used as an energy source of heat pumps for heat supply and electricity saving. Most coefficients of performance values of wastewater source heat pumps are in the range of 1.77-10.63 for heating and 2.23-5.35 for cooling [139]. The energy efficiency mainly depends on the design and operation of the heat exchangers for the heat pump system. Nowadays, the most commonly used heat pumps in WWTPs are on/off controlled fixed-speed type with low efficiency as they operate intermittently under severe load conditions. In addition, the scale deposit phenomenon usually decreases the performance of the heat pump system. Recently, a fixed-inverter hybrid heat pump system was designed to run in a real WWTP in South Korea, aimed at improving load response and maintaining high efficiency levels [140]. A novel dry-expansion shell-and-tube evaporator with a defouling function used in a heat pump system developed by Shen et.al achieved 3.1 times greater heat transfer coefficient than conventional systems [141].

Wind, solar, and hydroelectric energy may also be used as an on-site energy source. WWTPs with a change in elevation can generate hydroelectric power. However, it is difficult to directly use wind energy as traditional WWTPs are located at low elevations. In general, WWTPs with large horizontal surfaces are needed to extract solar energy, although the potential for solar energy contribution is relatively high from WWTPs with large area equipped with a photovoltaic system. Solar energy also 
can be applied in wastewater treatment through photocatalytic processes. For example, $\mathrm{ZnO}$ can be used as photocatalyst for the removal of hazardous pollutants like methylstyrene from wastewater [142]. Kiheung Respia WWTP is a representative municipal WWTP located in Yongin, Korea with a design capacity of 30,000 $\mathrm{m}^{3} / \mathrm{d}$. Chae et al. [64] investigated three kinds of energy resource at this WWTP, including photovoltaics, small hydropower, and thermal energy from effluent heat. The estimation of environment-friendly energy production at the WWTP (100 kW solar photovoltaics, $10 \mathrm{~kW}$ small hydropower, and $25 \mathrm{RT}(1 \mathrm{RT}=3.517 \mathrm{~kW})$ heat pump) suggested about $6.5 \%$ of energy self-sufficiency when the technology is properly installed and managed [64].

\subsection{Energy self-sufficient WWTPs construction: from theoretical analysis to practice}

In order to promote engineering applications of energy self-sufficient WWTPs, theoretical assessment of such systems is often required. Fig. 8 shows the energy self-sufficient WWTPs construction process from theoretical analysis to practice for both new WWTPs design and the improvement of existing WWTPs. An energy balance analysis is the key tool for choosing appropriate energy recovery technologies. However, theoretical energy balance analysis in WWTPs still remains undeveloped. LCA is usually used to analyze the energy and mass input and output flows in WWTPs during the construction phase, operation phase and demolishment phase [143, 144]. In a move away from LCA, recently, a multi-step methodology was developed for analysis of a WWTPs' energy balance focusing on direct energy consumption and generation in the plant, which has received interest from the operators of WWTPs [3]. Another theoretical model for the assessment of energy self-sufficiency in WWTPs named “net-zero-energy," has been developed mainly focused on the organic energy recovery in WWTPs based on AD of sludge. The net-zero-energy model included the mathematical derivation of the theoretical energy consumption for COD treatment, the energy requirement for the AD system and energy recovery from the CHP System [145]. Besides the energy balance analysis, cost is another important factor for the construction of energy self-sufficient WWTPs. The analysis of the initial investment and the benefit across the life cycle both need to be considered. It was estimated that a 
net-zero-energy WWTP with a capacity of $10,000 \mathrm{~m}^{3} / \mathrm{d}$ can save $\$ 100,000$ each year in China through energy self-sufficiency [145]. However, during the actual operating process, the operators need to constantly optimize the energy recovery sections though adjusting key parameters or through the adoption of advanced technologies to achieve energy independence with the lowest cost.

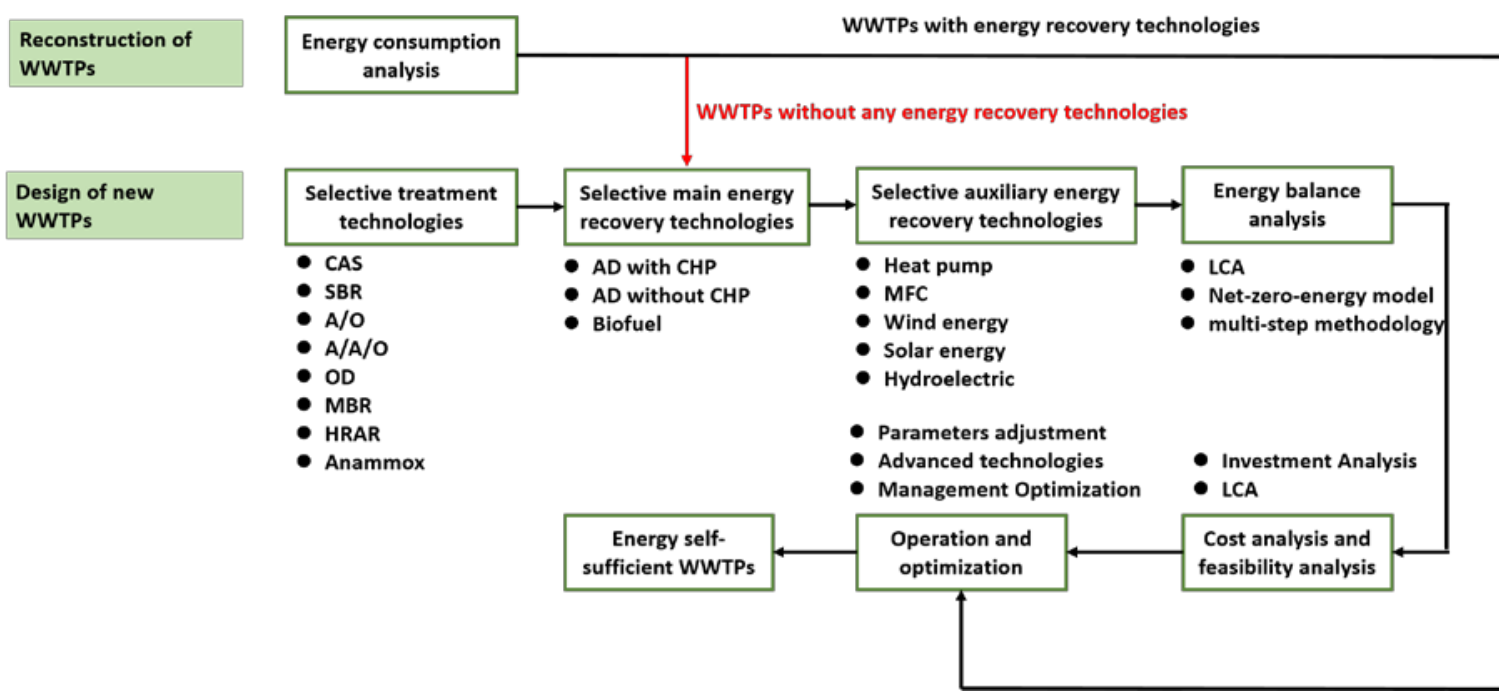

Fig. 8. The energy self-sufficient WWTPs construction process from theoretical analysis to practice.

\subsection{Examples of energy self-sufficient WWTPs}

For decades, energy efficiency optimization has been carried out in order to work towards energy self-sufficient WWTPs. Some examples of energy self-sufficient WWTPs have been constructed successfully. Shen et al. [76] have summarized the reported full-scale energy self-sufficient WWTPs in North America and Europe, reporting 12 WWTPs that have achieved $>90 \%$ energy self-sufficiency (Table 2).

Table 2. Energy self-sufficiency of full-scale WWTPs. Source: [76].

\begin{tabular}{llllll}
\hline No & Name of WWTPs & Location & $\begin{array}{c}\text { Capacity } \\
\text { (MGD) }\end{array}$ & $\begin{array}{l}\text { Energy } \\
\text { self-sufficiency (\%) }\end{array}$ & Reference(s) \\
\hline 1 & Grevesmuhlen & Germany & 4 & $100^{\mathrm{a}}$ & {$[146]$} \\
2 & Wolfgangsee-Ischl & Austria & 5 & $100^{\mathrm{b}}$ & {$[28,147]$} \\
3 & Strass im Zillertal & Austria & 6 & $100^{\mathrm{a}}$ & {$[15,148]$} \\
4 & Gloversville-Johnstown & USA & 11 & 100 & {$[149]$} \\
& Joint & & & & \\
\hline
\end{tabular}




\begin{tabular}{llllll}
\hline 5 & Sheboygan Regional & USA & 11 & 100 & {$[150]$} \\
6 & Gresham & USA & 13 & 100 & {$[151]$} \\
7 & Prague Central & Czech & 42 & 94 & {$[30,152]$} \\
& & Republic & & & \\
8 & Zürich Werdhölzli & Switzerland & 67 & 100 & {$[153]$} \\
9 & East Bay Municipal & USA & 70 & $100^{\mathrm{a}}$ & {$[76]$} \\
& Utility District & & & & {$[154,155]$} \\
10 & Point Loma & USA & 175 & 100 & {$[76,156]$} \\
11 & Davyhulme, & England & 200 & 96 & {$[76]$} \\
12 & Joint Water Pollution & USA & 300 & 97 & \\
\hline
\end{tabular}

Note a: Sale $>20 \%$, b: Sale $>10 \%$

The Howard F. Curren Advanced Wastewater Treatment System (HCWTP) located in Tampa, Florida is one of the state-of-the-art WWTPs with 54.2 million gallon/d (about 205,000 $\mathrm{m}^{3} / \mathrm{d}$ ) treatment capacity [27]. The treatment system in the HCWTP includes primary treatment, secondary treatment, nitrification, denitrification, post-aeration, and chlorine disinfection. Mo et al. [27] examined the potential available energy value by integrated resource (including energy, nutrient, and water) recovery in this WWTP via theoretical calculation. The recovery processes in this WWTP (Fig. 9) include embodied energy offset from water reuse, onsite energy generation, and nutrient recycling [27]. For HCWTP, electricity is produced onsite through five $500 \mathrm{~kW}$ engine generators using biogas from anaerobic digesters. Theoretical calculation shows that integrated resource recovery possesses can offset all the direct energy requirement for the operation of the WWTP. However, this technique cannot offset the overall energy for implementation of treatment processing to achieve carbon neutrality. The East Bay Municipal Utility District (EBMUD) wastewater treatment facility in Oakland, USA with 70 MGD (about 265,000 $\mathrm{m}^{3} / \mathrm{d}$ ) treatment capacity became the first self-sufficient WWTP in North America in 2012 [76]. Biogas production is almost improved $70 \%$ by co-digestion with food waste, 
winery waste and oil in EBMUD. EBMUD also expands the total power generation of the WWTP to more than $11 \mathrm{MW}$, such expansion results from the installation of a 4.6 MW jet engine-sized turbine to handle the current $38,000 \mathrm{~m}^{3} / \mathrm{d}$ of biogas production [76]. The overall electricity produced in EBMUD is 126\% of this WWTP's electric demand, meaning that, the excess electricity produced can be sold to the grid. The Sheboygan Wastewater Treatment Plant (located in the U.S.) is another example of a nearly 100\% energy self-sufficient WWTP. This WWTP utilizes an activated sludge process to achieve secondary wastewater treatment. To date, this WWTP can produce nearly $90 \%$ of its annual electrical energy and $85 \%$ of its annual heat requirements on site using a co-digestion program creating $700 \mathrm{~kW}$ of cogeneration capacity [157].

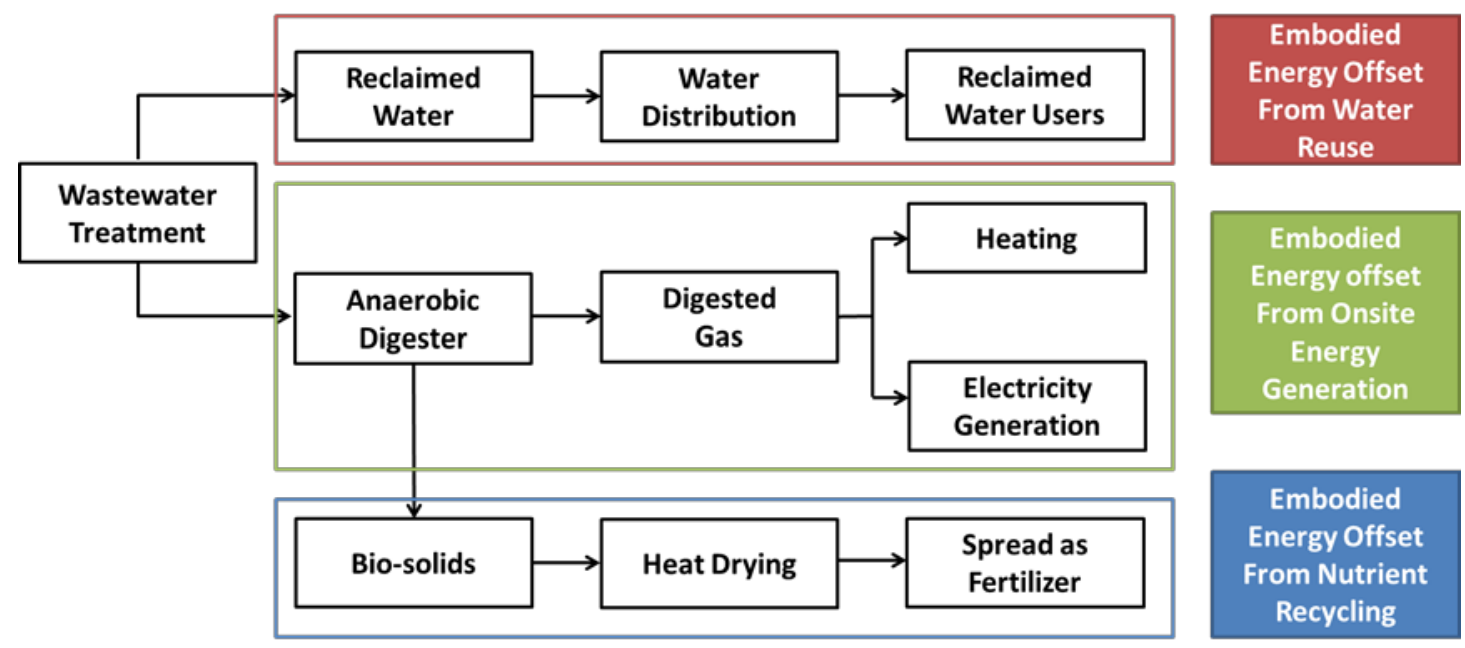

Fig. 9. Integrated recovery processes in the HCWTP. Source: [27]

The Strass and Wolfgangsee-Ischl WWTPs in Austria are both typical 100\% energy self-sufficient WWTPs. The energy balance of these two cases are shown in Fig. 10 [28]. For the Strass WWTP, on average, $21.4 \mathrm{kWh} /\left(\mathrm{pe}_{120 . \mathrm{a}}\right)\left(\mathrm{pe}_{120}=\right.$ population equivalents related to $120 \mathrm{~g}$ COD/d) of electric energy was produced through biogas from anaerobic digestion of sludge during 2005-2007. As shown in Fig. 10a, the total electricity consumed in the WWTP was $19.9 \mathrm{kWh} / \mathrm{pe}_{120} . \mathrm{a}$, of which $9.1 \mathrm{kWh} /\left(\mathrm{pe}_{120} . \mathrm{a}\right)$ was consumed by aerating and stirring of the aeration tank, and the remaining 10.8 $\mathrm{kWh} / \mathrm{pe}_{120}$.a was consumed by other treatment processes. For the Wolfgangsee-Ischl WWTP on average, $20.6 \mathrm{kWh} /\left(\mathrm{pe}_{120} . \mathrm{a}\right)$ of electrical energy was produced from digester gas from September 2009 to August 2010 (Fig. 10b). Similar to the Strass 
WWTP, surplus electric energy is sold to the grid $\left(2.2 \mathrm{kWh} /\left(\mathrm{pe}_{120} . \mathrm{a}\right)\right)$, while for peak energy demand, electricity was obtained from the grid. The total electricity consumed in Wolfgangsee-Ischl was $19.2 \mathrm{kWh} /\left(\mathrm{pe}_{120 . \mathrm{a}}\right)$, of which $11.5 \mathrm{kWh} /\left(\mathrm{pe}_{120} . \mathrm{a}\right)$ was consumed by aerating and stirring the aeration tank, and the remaining 7.7 $\mathrm{kWh} /\left(\mathrm{pe}_{120} . \mathrm{a}\right)$ was consumed by other treatment processes.
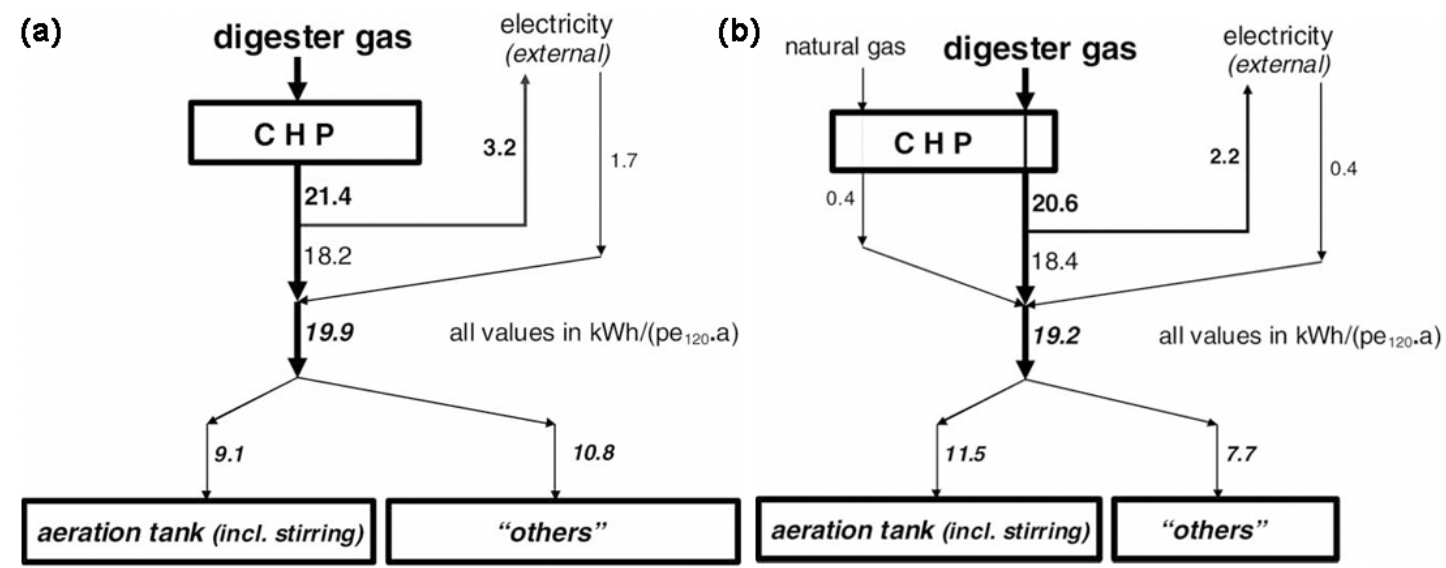

Fig. 10. (a) Energy balance of the Strass WWTP in 2005-2007. (b) Energy balance of Wolfgangsee-Ischl WWTP from September, 2009 to August, 2010. Adapted from [28].

\subsection{Challenges of constructing energy self-sufficient WWTPs}

Full energy self-sufficient wastewater treatment can be possibly achieved through a combination of energy recovery and improved energy efficiency [22, 28, 146, 158]. Nevertheless, there are few WWTPs that satisfy both energy and carbon neutrality. Currently, less than $10 \%$ of WWTPs in USA are producing surplus biogas for commercial use [70]. There are currently no high-energy self-sufficient (>90\%) WWTPs in developing countries, where a large gap for energy self-sufficient WWTPs still exists.

The establishment of energy self-sufficient WWTPs presents many limitations in terms of technological barriers and environmental protection issues, with still much ongoing research of technologies which were developed several decades ago. For example, Anammox technologies were developed in 1977, yet the mainstream application of these technologies is still under trial and investigation [159]. WWTPs 
of different sizes pose different problems, for example it will be difficult to realize complete energy independence in WWTPs with a low load. Cost is also an issue in the establishment of energy self-sufficient WWTPs as the upfront input in constructing an energy self-sufficient WWTP is more expensive than constructing a traditional one, wit home technologies in particular, such as CHP and photovoltaics, requiring large investment of development [80, 160.] In terms of environmental protection, inadequate anaerobic treatment may influence the adjacent environment, and $\mathrm{CH}_{4}$ and $\mathrm{N}_{2} \mathrm{O}$ leakages may contribute to global warming and air pollution [77, 147].

The best combination of different kinds of potential energy sources needs to be determined based on the actual conditions in different areas $[64,138]$. Therefore, a wide range of possible factors should be considered using state-of-the-art models, such as LCA, to evaluate the total benefit and select the most suitable technologies for energy self-sufficient WWTPs [77]. Given that existing WWTPS may not have the infrastructure to recover energy as part of the process, established WWTPs can still improve their energy efficiency. According to a case study on improving the energy efficiency of 14 WWTPs in Portugal, energy-saving efficiency can vary from 20\% to $40 \%$ and even more in some specific cases [161]. Currently, numerous break-through solutions and optimized procedures for both energy generation and increased energy efficiency are still under investigation. None of the approaches discussed can be singled out as the ideal one to solve all problems in all situations, yet all the systems still have the potential to be optimized to recover and save large amount of energy. There is evidence from the studies presented that rather than focusing on single techniques, the different techniques presented can be integrated with one another on the basis of the specific required condition to provide optimal results.

\section{Conclusion}

This paper has summarised the different energy consumption in WWTPs associated with different technologies from different WWTPS from around the world, and explored the potential of energy self-sufficiency in WWTPs. Aeration and additional sludge treatment are energy-intensive process in WWTPs. Furthermore, specific energy demand in WWTPs decreases with increasing inflow and increases with 
increasing concentration of pollutants in the influent ( $\mathrm{COD}, \mathrm{BOD}_{5}$, and nitrogen). International benchmarking can be used to increase understanding of energy efficiency in WWTPs because energy consumption in different regions are different, because of differences in WWTP technology and target effluent quality.

Although there is more that can still be done, energy efficiency optimization has long been a part of the design and construction of WWTPs and is an important component of constructing energy self-sufficient WWTPs. Currently, most energy self-sufficient WWTPs are using biogas from the anaerobic digestion of sludge for digester heating and electricity generation. In some case, wind, solar, and hydroelectric energy may also be used as energy contributions. Recent advances in the optimization of energy generation technologies, and theoretical analysis model have been summarized. Although energy self-sufficient WWTPs are definitely feasible, many challenges still exist, particularly in developing countries and further efforts are needed in terms of addressing technology, costs, and environmental protection issues.

\section{Acknowledgement}

This work was partly sponsored by Beijing Environment Foundation for Young Talents. We thank the committee of The ICAE 2016: 18th International Conference on Applied Energy and anonymous referees for their comments and suggestions. We also thank Miss Xiru Li from Macquarie University, Australia for her assistance with manuscript proofreading.

\section{Reference}

[1] Enger ED, Smith BF, Bockarie AT. Environmental science: A study of interrelationships: McGraw-Hill Boston; 2000.

[2] Rojas J, Zhelev T. Energy efficiency optimisation of wastewater treatment: Study of ATAD. Computers \& Chemical Engineering. 2012;38:52-63.

[3] Panepinto D, Fiore S, Zappone M, Genon G, Meucci L. Evaluation of the energy efficiency of a large wastewater treatment plant in Italy. Applied Energy. 2016;161:404-11.

[4] Scott CA, Pierce SA, Pasqualetti MJ, Jones AL, Montz BE, Hoover JH. Policy and institutional dimensions of the water-energy nexus. Energy Policy. 2011;39:6622-30.

[5] Hardy L, Garrido A, Juana L. Evaluation of Spain's water-energy nexus. International Journal of Water Resources Development. 2012;28:151-70. 
[6] Kahrl F, Roland-Holst D. China's water-energy nexus. Water Policy. 2008;10:51-65.

[7] Kenney DS, Wilkinson R. The water-energy nexus in the American West: Edward Elgar Publishing; 2011.

[8] Lofman D, Petersen M, Bower A. Water, energy and environment nexus: The California experience. International Journal of Water Resources Development. 2002;18:73-85.

[9] Malik R. Water-energy nexus in resource-poor economies: the Indian experience. International Journal of Water Resources Development. 2002;18:47-58.

[10] Siddiqi A, Anadon LD. The water-energy nexus in Middle East and North Africa. Energy policy. 2011;39:4529-40.

[11] Lazarova V, Choo K-H, Cornel P. Water-energy interactions in water reuse: IWA publishing; 2012.

[12] Englehardt JD, Wu T, Bloetscher F, Deng Y, du Pisani P, Eilert S, et al. Net-zero water management: achieving energy-positive municipal water supply. Environmental Science: Water Research \& Technology. 2016;2:250-60.

[13] Friedrich E, Pillay S, Buckley C. Environmental life cycle assessments for water treatment processes a South African case study of an urban water cycle. Water SA. 2009;35:73-84.

[14] Dincer I. The role of exergy in energy policy making. Energy policy. 2002;30:137-49.

[15] Wett B, Buchauer K, Fimml C. Energy self-sufficiency as a feasible concept for wastewater treatment systems. IWA Leading Edge Technology Conference: Singa-pore: Asian Water; 2007. p. 21-4.

[16] Gu Y, Dong Y-n, Wang H, Keller A, Xu J, Chiramba T, et al. Quantification of the water, energy and carbon footprints of wastewater treatment plants in China considering a water-energy nexus perspective. Ecological Indicators. 2016;60:402-9.

[17] Ashrafi O, Yerushalmi L, Haghighat F. Greenhouse gas emission and energy consumption in wastewater treatment plants: impact of operating parameters. CLEAN-Soil, Air, Water. 2014;42:207-20.

[18] Shahabadi MB, Yerushalmi L, Haghighat F. Impact of process design on greenhouse gas (GHG) generation by wastewater treatment plants. Water Research. 2009;43:2679-87.

[19] Pan T, Zhu X-D, Ye Y-P. Estimate of life-cycle greenhouse gas emissions from a vertical subsurface flow constructed wetland and conventional wastewater treatment plants: A case study in China. Ecol Eng. 2011;37:248-54.

[20] Shahabadi MB, Yerushalmi L, Haghighat F. Estimation of greenhouse gas generation in wastewater treatment plants-Model development and application. Chemosphere. 2010;78:1085-92.

[21] Singh P, Carliell-Marquet C, Kansal A. Energy pattern analysis of a wastewater treatment plant. Applied Water Science. 2012;2:221-6.

[22] Awe OW, Liu R, Zhao Y. Analysis of Energy Consumption and Saving in Wastewater Treatment Plant: Case Study from Ireland. Journal of Water Sustainability. 2016;6:63-76.

[23] Matos C, Pereira S, Amorim E, Bentes I, Briga-Sá A. Wastewater and greywater reuse on irrigation in centralized and decentralized systems - an integrated approach on water quality, energy consumption and CO 2 emissions. Science of the total environment. 2014;493:463-71.

[24] Estrada JM, Lebrero R, Quijano G, Kraakman NB, Muñoz R. Odour abatement technologies in WWTPs: energy and economic efficiency. Sewage Treatment Plants: Economic Evaluation of Innovative Technologies for Energy Efficiency. 2015:163.

[25] McCarty PL, Bae J, Kim J. Domestic wastewater treatment as a net energy producer-can this be achieved? : ACS Publications; 2011. 
[26] Guest JS, Skerlos SJ, Barnard JL, Beck MB, Daigger GT, Hilger H, et al. A new planning and design paradigm to achieve sustainable resource recovery from wastewater 1. ACS Publications; 2009.

[27] Mo W, Zhang Q. Can municipal wastewater treatment systems be carbon neutral? Journal of environmental management. 2012;112:360-7.

[28] Nowak O, Keil S, Fimml C. Examples of energy self-sufficient municipal nutrient removal plants. Water Sci Technol. 2011;64:1-6.

[29] Jenicek P, Bartacek J, Kutil J, Zabranska J, Dohanyos M. Potentials and limits of anaerobic digestion of sewage sludge: Energy self-sufficient municipal wastewater treatment plant? Water Sci Technol. 2012;66:1277-81.

[30] Jenicek P, Kutil J, Benes O, Todt V, Zabranska J, Dohanyos M. Energy self-sufficient sewage wastewater treatment plants: is optimized anaerobic sludge digestion the key? Water Sci Technol. 2013;68:1739-44.

[31] Plappally A. Energy requirements for water production, treatment, end use, reclamation, and disposal. Renewable and Sustainable Energy Reviews. 2012;16:4818-48.

[32] Bodik I, Kubaská M. Energy and sustainability of operation of a wastewater treatment plant. Environment Protection Engineering. 2013;39:15--24.

[33] Projections CC, Sanderson B, Knutti R. ENCYCLOPEDIA OF SUSTAINABILITY SCIENCE AND TECHNOLOGY.

[34] Pitas V, Fazekas B, Banyai Z, Karpati A. Energy efficiency of the municipal wastewater treatment. Journal of Biotechnology. 2010;150, Supplement:163-4.

[35] Kneppers B, Birchfield D, Reviewer ML, Easton L, Collins N, Wilson D, et al. Energy-Water Relationships in Reticulated Water Infrastructure Systems. Water Supply (kWh/Capita), 2009.

[36] Liu F, Ouedraogo A, Manghee S, Danilenko A. A primer on energy efficiency for municipal water and wastewater utilities. 2012.

[37] Mamais D, Noutsopoulos C, Dimopoulou A, Stasinakis A, Lekkas T. Wastewater treatment process impact on energy savings and greenhouse gas emissions. Water Sci Technol. 2015;71:303-8.

[38] Walther E. Energy Efficiency and GHG Reduction in Wastewater Facilities. Northern California Chapter Meeting2009.

[39] Mizuta K, Shimada M. Benchmarking energy consumption in municipal wastewater treatment plants in Japan. Water Sci Technol. 2010;62:2256-62.

[40] Yang L, Zeng S, Chen J, He M, Yang W. Operational energy performance assessment system of municipal wastewater treatment plants. Water Sci Technol. 2010;62:1361-70.

[41] Tao G, Kekre K, Oo MH, Viswanath B, Yusof AM, Seah H. Energy reduction and optimisation in membrane bioreactor systems. Water Practice and Technology. 2010;5:wpt2010088.

[42] Brepols C. Operating large scale membrane bioreactors for municipal wastewater treatment: IWA publishing; 2010.

[43] Palmowski L VK, Pinnekamp J. Optimization measures of large MBR plants to lower energy consumption. 6th IWA Specialist Conference on Membrane Technology for Water and Wastewater Treatment. Aachen (Germany)2011.

[44] Krzeminski P, van der Graaf JH, van Lier JB. Specific energy consumption of membrane bioreactor (MBR) for sewage treatment. Water Sci Technol. 2012;65:380-92.

[45] Cornel P, Wagner M, Krause S. Investigation of oxygen transfer rates in full scale membrane bioreactors. Water Sci Technol. 2003;47:313-9.

[46] Barillon B, Ruel SM, Langlais C, Lazarova V. Energy efficiency in membrane bioreactors. Water 
Sci Technol. 2013;67:2685-91.

[47] Li J, Ge Z, He Z. Advancing membrane bioelectrochemical reactor (MBER) with hollow - fiber membranes installed in the cathode compartment. Journal of Chemical Technology and Biotechnology. 2014;89:1330-6.

[48] Newell T, Batista JR, Ahmad S, Johnson W. Energy Consumption in Large Wastewater Treatment Plants as a Function of Wastewater Strength. 2012.

[49] Schnoor JL. Water-Energy Nexus. Environmental Science \& Technology. 2011;45:5065-.

[50] Wakeel M, Chen B, Hayat T, Alsaedi A, Ahmad B. Energy consumption for water use cycles in different countries: A review. Applied Energy. 2016;178:868-85.

[51] Arnold M, Merta E. Towards energy self-sufficiency in wastewater treatment by optimized sludge treatment. Water Practice and Technology. 2011;6:wpt20110069.

[52] Goldstein R SW. US electricity consumption for water supply \& treatment-the next half century. Water \& sustainability: Electric Power Research Institute; 2002.

[53] Xie T, Wang C, Wang C. Energy Consumption in Wastewater Treatment Plants in China. World Congress on Water, Climate and Energy2012.

[54] Longo S, d'Antoni BM, Bongards M, Chaparro A, Cronrath A, Fatone F, et al. Monitoring and diagnosis of energy consumption in wastewater treatment plants. A state of the art and proposals for improvement. Applied Energy. 2016;179:1251-68.

[55] Sobańtka A, Rechberger H. Extended statistical entropy analysis (eSEA) for improving the evaluation of Austrian wastewater treatment plants. Water Sci Technol. 2013;67:1051-7.

[56] Libralato G, Ghirardini AV, Avezzù F. To centralise or to decentralise: An overview of the most recent trends in wastewater treatment management. Journal of Environmental Management. 2012;94:61-8.

[57] van Afferden M, Cardona JA, Lee M-Y, Subah A, Müller RA. A new approach to implementing decentralized wastewater treatment concepts. Water Sci Technol. 2015;72:1923-30.

[58] Singh NK, Kazmi A, Starkl M. A review on full-scale decentralized wastewater treatment systems: techno-economical approach. Water Sci Technol. 2015;71:468-78.

[59] Chen Z, Wu Q, Wu G, Hu H-Y. Centralized water reuse system with multiple applications in urban areas: Lessons from China's experience. Resources, Conservation and Recycling. 2017;117:125-36.

[60] Shehabi A, Stokes JR, Horvath A. Energy and air emission implications of a decentralized wastewater system. Environmental Research Letters. 2012;7:024007.

[61] Opher T, Friedler E. Comparative LCA of decentralized wastewater treatment alternatives for non-potable urban reuse. Journal of environmental management. 2016;182:464-76.

[62] Jonasson M, Ulf Jeppsson I. Energy Benchmark for Wastewater Treatment Processes: MS Thesis, 2007, Dept. of Industrial Electrical Engineering and Automation Lund University; 2007.

[63] Wang H, Yang Y, Keller AA, Li X, Feng S, Dong Y-n, et al. Comparative analysis of energy intensity and carbon emissions in wastewater treatment in USA, Germany, China and South Africa. Applied Energy. 2016;184:873-81.

[64] Chae K-J, Kang J. Estimating the energy independence of a municipal wastewater treatment plant incorporating green energy resources. Energy conversion and Management. 2013;75:664-72.

[65] Olsson G. Water and Energy Nexus. In: Meyers RA, editor. Encyclopedia of Sustainability Science and Technology. New York, NY: Springer New York; 2012. p. 11932-46.

[66] Hernández-Sancho F, Molinos-Senante M, Sala-Garrido R. Energy efficiency in Spanish wastewater treatment plants: a non-radial DEA approach. Science of the Total Environment. 
2011;409:2693-9.

[67] Jin L, Zhang G, Tian H. Current state of sewage treatment in China. Water research. 2014;66:85-98.

[68] Edward III G. Water and wastewater industry energy efficiency: a research roadmap: Awwa Research Foundation; 2004.

[69] Wang X, Liu J, Ren N-Q, Yu H-Q, Lee D-J, Guo X. Assessment of multiple sustainability demands for wastewater treatment alternatives: a refined evaluation scheme and case study. Environmental science \& technology. 2012;46:5542-9.

[70] Hao X, Batstone D, Guest JS. Carbon neutrality: An ultimate goal towards sustainable wastewater treatment plants. Water research. 2015;87:413-5.

[71] Svardal K, Kroiss H. Energy requirements for waste water treatment. Water Sci Technol. 2011;64:1355-61.

[72] Frijns J, Hofman J, Nederlof M. The potential of (waste) water as energy carrier. Energy Conversion and Management. 2013;65:357-63.

[73] Logan BE. Simultaneous wastewater treatment and biological electricity generation. Water Sci Technol. 2005;52:31-7.

[74] Bennett A. Processing petrochemicals: Reverse osmosis in petrochemicals. Filtration \& Separation. 2007;44:16-9.

[75] Silvestre G, Fernández B, Bonmatí A. Significance of anaerobic digestion as a source of clean energy in wastewater treatment plants. Energy Conversion and Management. 2015;101:255-62.

[76] Shen Y, Linville JL, Urgun-Demirtas M, Mintz MM, Snyder SW. An overview of biogas production and utilization at full-scale wastewater treatment plants (WWTPs) in the United States: challenges and opportunities towards energy-neutral WWTPs. Renewable and Sustainable Energy Reviews. 2015;50:346-62.

[77] Schaubroeck T, De Clippeleir H, Weissenbacher N, Dewulf J, Boeckx P, Vlaeminck SE, et al. Environmental sustainability of an energy self-sufficient sewage treatment plant: improvements through DEMON and co-digestion. water research. 2015;74:166-79.

[78] Remy C, Lesjean B. Optimisation of energy and nutrient recovery in wastewater treatment schemes

(http://www.kompetenz-wasser.de/fileadmin/user_upload/pdf/forschung/CoDiGreen/CoDiGreen_Exec utive_Summary-final_01.pdf). 2012.

[79] Sheboygan-WWTP. http://www.sheboyganwwtp.com/index.php. 2015.

[80] EPA C. Opportunities for and benefits of combined heat and power at wastewater treatment facilities. EPA-430-R-07-003, 6; 2007.

[81] Smith AL, Stadler LB, Cao L, Love NG, Raskin L, Skerlos SJ. Navigating wastewater energy recovery strategies: a life cycle comparison of anaerobic membrane bioreactor and conventional treatment systems with anaerobic digestion. Environmental science \& technology. 2014;48:5972-81.

[82] Remy C, Boulestreau M, Lesjean B. Proof of concept for a new energy-positive wastewater treatment scheme. Water Sci Technol. 2014;70:1709-16.

[83] Meerburg FA, Boon N, Van Winckel T, Vercamer JA, Nopens I, Vlaeminck SE. Toward energy-neutral wastewater treatment: A high-rate contact stabilization process to maximally recover sewage organics. Bioresource technology. 2015;179:373-81.

[84] Ge H, Batstone DJ, Keller J. Operating aerobic wastewater treatment at very short sludge ages enables treatment and energy recovery through anaerobic sludge digestion. Water research. 
2013;47:6546-57.

[85] Wei C-H, Harb M, Amy G, Hong P-Y, Leiknes T. Sustainable organic loading rate and energy recovery potential of mesophilic anaerobic membrane bioreactor for municipal wastewater treatment. Bioresource technology. 2014;166:326-34.

[86] Ruffino B, Campo G, Genon G, Lorenzi E, Novarino D, Scibilia G, et al. Improvement of anaerobic digestion of sewage sludge in a wastewater treatment plant by means of mechanical and thermal pre-treatments: performance, energy and economical assessment. Bioresource technology. 2015;175:298-308.

[87] Farno E, Baudez JC, Parthasarathy R, Eshtiaghi N. Net positive energy wastewater treatment plant via thermal pre-treatment of sludge: A theoretical case study. Journal of Environmental Science and Health, Part A. 2017:1-4.

[88] K K. Study of Anaerobic Co-Digestion of Sludge in Sewage Mixed with Organic Wastes. Shanghai Coustruction Science \& Technology. 2005.

[89] Koch K, Helmreich B, Drewes JE. Co-digestion of food waste in municipal wastewater treatment plants: effect of different mixtures on methane yield and hydrolysis rate constant. Applied Energy. 2015;137:250-5.

[90] Kosse P, Lübken M, Wichern M. Urban lignocellulosic biomass can significantly contribute to energy production in municipal wastewater treatment plants-A GIS-based approach for a metropolitan area. Biomass and Bioenergy. 2015;81:568-73.

[91] Strous M, Heijnen J, Kuenen J, Jetten M. The sequencing batch reactor as a powerful tool for the study of slowly growing anaerobic ammonium-oxidizing microorganisms. Applied microbiology and biotechnology. 1998;50:589-96.

[92] Gao D-W, Tao Y. Versatility and application of anaerobic ammonium-oxidizing bacteria. Applied microbiology and biotechnology. 2011;91:887-94.

[93] Lackner S, Gilbert EM, Vlaeminck SE, Joss A, Horn H, van Loosdrecht MC. Full-scale partial nitritation/anammox experiences-an application survey. Water research. 2014;55:292-303.

[94] Puyol D, Carvajal-Arroyo J, Sierra-Alvarez R, Field JA. Nitrite (not free nitrous acid) is the main inhibitor of the anammox process at common pH conditions. Biotechnology letters. 2014;36:547-51.

[95] Joss A, Salzgeber D, Eugster J, König R, Rottermann K, Burger S, et al. Full-scale nitrogen removal from digester liquid with partial nitritation and anammox in one SBR. Environmental Science \& Technology. 2009;43:5301-6.

[96] Abma W, Driessen W, Haarhuis R, Van Loosdrecht M. Upgrading of sewage treatment plant by sustainable and cost-effective separate treatment of industrial wastewater. Water Sci Technol. 2010;61:1715-22.

[97] Bauer H, Johnson TD, Johnson BR, Oerke D, Graziano S. Comparison of sidestream treatment technologies: post aerobic digestion and Anammox. Water Sci Technol. 2016;73:2789-803.

[98] Dai W, Xu X, Liu B, Yang F. Toward energy-neutral wastewater treatment: a membrane combined process of anaerobic digestion and nitritation-anammox for biogas recovery and nitrogen removal. Chemical Engineering Journal. 2015;279:725-34.

[99] Desloover J, De Clippeleir H, Boeckx P, Du Laing G, Colsen J, Verstraete W, et al. Floc-based sequential partial nitritation and anammox at full scale with contrasting $\mathrm{N} 2 \mathrm{O}$ emissions. Water Research. 2011;45:2811-21.

[100] Gao D-W, Lu J-C, Liang H. Simultaneous energy recovery and autotrophic nitrogen removal from sewage at moderately low temperatures. Applied microbiology and biotechnology. 
2014;98:2637-45.

[101] Kartal B, Kuenen J, Van Loosdrecht M. Sewage treatment with anammox. Science. 2010;328:702-3.

[102] Ni S-Q, Zhang J. Anaerobic ammonium oxidation: from laboratory to full-scale application. BioMed research international. 2013;2013.

[103] Aelterman P, Rabaey K, Clauwaert P, Verstraete W. Microbial fuel cells for wastewater treatment. Water Sci Technol. 2006;54:9-15.

[104] Ghangrekar M, Shinde V. Performance of membrane-less microbial fuel cell treating wastewater and effect of electrode distance and area on electricity production. Bioresource Technology. 2007;98:2879-85.

[105] Ghangrekar M, Shinde V. Simultaneous sewage treatment and electricity generation in membrane-less microbial fuel cell. Water Sci Technol. 2008;58:37-43.

[106] Liu H, Ramnarayanan R, Logan BE. Production of electricity during wastewater treatment using a single chamber microbial fuel cell. Environmental science \& technology. 2004;38:2281-5.

[107] Min B, Logan BE. Continuous electricity generation from domestic wastewater and organic substrates in a flat plate microbial fuel cell. Environmental science \& technology. 2004;38:5809-14.

[108] Rodrigo M, Canizares P, Lobato J, Paz R, Sáez C, Linares J. Production of electricity from the treatment of urban waste water using a microbial fuel cell. Journal of Power Sources. 2007;169:198-204.

[109] Sevda S, Dominguez-Benetton X, Vanbroekhoven K, De Wever H, Sreekrishnan T, Pant D. High strength wastewater treatment accompanied by power generation using air cathode microbial fuel cell. Applied energy. 2013;105:194-206.

[110] Li W-W, Yu H-Q, He Z. Towards sustainable wastewater treatment by using microbial fuel cells-centered technologies. Energy \& Environmental Science. 2014;7:911-24.

[111] Pham T, Rabaey K, Aelterman P, Clauwaert P, De Schamphelaire L, Boon N, et al. Microbial fuel cells in relation to conventional anaerobic digestion technology. Engineering in Life Sciences. 2006;6:285-92.

[112] Ahn Y, Logan BE. Effectiveness of domestic wastewater treatment using microbial fuel cells at ambient and mesophilic temperatures. Bioresource technology. 2010;101:469-75.

[113] Lefebvre O, Uzabiaga A, Chang IS, Kim B-H, Ng HY. Microbial fuel cells for energy self-sufficient domestic wastewater treatment-a review and discussion from energetic consideration. Applied microbiology and biotechnology. 2011;89:259-70.

[114] He Z. Microbial Fuel Cells: Now Let us Talk about Energy. Environmental Science \& Technology. 2013;47:332-3.

[115] Oh ST, Kim JR, Premier GC, Lee TH, Kim C, Sloan WT. Sustainable wastewater treatment: how might microbial fuel cells contribute. Biotechnology advances. 2010;28:871-81.

[116] Rozendal RA, Hamelers HV, Rabaey K, Keller J, Buisman CJ. Towards practical implementation of bioelectrochemical wastewater treatment. Trends in biotechnology. 2008;26:450-9.

[117] Feng Y, He W, Liu J, Wang X, Qu Y, Ren N. A horizontal plug flow and stackable pilot microbial fuel cell for municipal wastewater treatment. Bioresource technology. 2014;156:132-8.

[118] Dong Y, Qu Y, He W, Du Y, Liu J, Han X, et al. A 90-liter stackable baffled microbial fuel cell for brewery wastewater treatment based on energy self-sufficient mode. Bioresource technology. 2015;195:66-72.

[119] Mateo - Ramírez F, Addi H, Hernández - Fernández FJ, Godínez C, Pérez de los Ríos A, Lotfi 
EM, et al. Air breathing cathode - microbial fuel cell with separator based on ionic liquid applied to slaughterhouse wastewater treatment and bio - energy production. Journal of Chemical Technology and Biotechnology. 2016.

[120] Oon Y-L, Ong S-A, Ho L-N, Wong Y-S, Dahalan FA, Oon Y-S, et al. Role of macrophyte and effect of supplementary aeration in up-flow constructed wetland-microbial fuel cell for simultaneous wastewater treatment and energy recovery. Bioresource Technology. 2017;224:265-75.

[121] Su X, Tian Y, Sun Z, Lu Y, Li Z. Performance of a combined system of microbial fuel cell and membrane bioreactor: wastewater treatment, sludge reduction, energy recovery and membrane fouling. Biosensors and Bioelectronics. 2013;49:92-8.

[122] Li Y, Liu L, Yang F, Ren N. Performance of carbon fiber cathode membrane with C-Mn-Fe-O catalyst in MBR-MFC for wastewater treatment. Journal of Membrane Science. 2015;484:27-34.

[123] Wang Y-K, Sheng G-P, Shi B-J, Li W-W, Yu H-Q. A novel electrochemical membrane bioreactor as a potential net energy producer for sustainable wastewater treatment. Scientific reports. 2013;3:1864.

[124] Tian Y, Ji C, Wang K, Le-Clech P. Assessment of an anaerobic membrane bio-electrochemical reactor (AnMBER) for wastewater treatment and energy recovery. Journal of Membrane Science. 2014;450:242-8.

[125] Zhou G, Zhou Y, Zhou G, Lu L, Wan X, Shi H. Assessment of a novel overflow-type electrochemical membrane bioreactor (EMBR) for wastewater treatment, energy recovery and membrane fouling mitigation. Bioresource technology. 2015;196:648-55.

[126] Werner CM, Logan BE, Saikaly PE, Amy GL. Wastewater treatment, energy recovery and desalination using a forward osmosis membrane in an air-cathode microbial osmotic fuel cell. Journal of membrane science. 2013;428:116-22.

[127] Hou D, Lu L, Ren ZJ. Microbial fuel cells and osmotic membrane bioreactors have mutual benefits for wastewater treatment and energy production. Water research. 2016;98:183-9.

[128] Ren L, Ahn Y, Logan BE. A two-stage microbial fuel cell and anaerobic fluidized bed membrane bioreactor (MFC-AFMBR) system for effective domestic wastewater treatment. Environmental science \& technology. 2014;48:4199-206.

[129] Li J, Ge Z, He Z. A fluidized bed membrane bioelectrochemical reactor for energy-efficient wastewater treatment. Bioresource technology. 2014;167:310-5.

[130] Dong Y, Feng Y, Qu Y, Du Y, Zhou X, Liu J. A combined system of microbial fuel cell and intermittently aerated biological filter for energy self-sufficient wastewater treatment. Scientific reports. 2015;5.

[131] Muga HE, Mihelcic JR. Sustainability of wastewater treatment technologies. Journal of environmental management. 2008;88:437-47.

[132] Craggs RJ, Lundquist TJ, Benemann JR. Wastewater treatment and algal biofuel production. Algae for Biofuels and Energy: Springer; 2013. p. 153-63.

[133] Mehrabadi A, Craggs R, Farid MM. Wastewater treatment high rate algal ponds (WWT HRAP) for low-cost biofuel production. Bioresource technology. 2015;184:202-14.

[134] Kligerman DC, Bouwer EJ. Prospects for biodiesel production from algae-based wastewater treatment in Brazil: A review. Renewable and Sustainable Energy Reviews. 2015;52:1834-46.

[135] Craggs R, Park J, Heubeck S, Sutherland D. High rate algal pond systems for low-energy wastewater treatment, nutrient recovery and energy production. New Zealand Journal of Botany. 2014;52:60-73. 
[136] Zhou Y, Schideman L, Yu G, Zhang Y. A synergistic combination of algal wastewater treatment and hydrothermal biofuel production maximized by nutrient and carbon recycling. Energy \& Environmental Science. 2013;6:3765-79.

[137] Lindström H. Experiences with a 3.3 MW heat pump using sewage water as heat source. Journal of heat recovery systems. 1985;5:33-8.

[138] Hao X, Liu R, Huang X. Evaluation of the potential for operating carbon neutral WWTPs in China. Water research. 2015;87:424-31.

[139] Hepbasli A, Biyik E, Ekren O, Gunerhan H, Araz M. A key review of wastewater source heat pump (WWSHP) systems. Energy Conversion and Management. 2014;88:700-22.

[140] Chae K-J, Ren X. Flexible and stable heat energy recovery from municipal wastewater treatment plants using a fixed-inverter hybrid heat pump system. Applied Energy. 2016;179:565-74.

[141] Shen C, Jiang Y, Yao Y, Wang X. An experimental comparison of two heat exchangers used in wastewater source heat pump: A novel dry-expansion shell-and-tube evaporator versus a conventional immersed evaporator. Energy. 2012;47:600-8.

[142] Rajeev B, Yesodharan S, Yesodharan E. Application of solar energy in wastewater treatment: Photocatalytic degradation of $\alpha$-methylstyrene in water in presence of ZnO. Journal of Water Process Engineering. 2015;8:108-18.

[143] Pasqualino JC, Meneses M, Abella M, Castells F. LCA as a decision support tool for the environmental improvement of the operation of a municipal wastewater treatment plant. Environmental science \& technology. 2009;43:3300-7.

[144] Zhang Q, Wang X, Xiong J, Chen R, Cao B. Application of life cycle assessment for an evaluation of wastewater treatment and reuse project-Case study of Xi'an, China. Bioresource technology. 2010;101:1421-5.

[145] Yan P, Qin R, Guo J, Yu Q, Li Z, Chen Y-P, et al. A net-zero energy model for sustainable wastewater treatment. Environmental Science \& Technology. 2016.

[146] Schwarzenbeck N, Pfeiffer W, Bomball E. Can a wastewater treatment plant be a powerplant? A case study. Water Sci Technol. 2008;57:1555-61.

[147] Nowak O, Enderle P, Varbanov P. Ways to optimize the energy balance of municipal wastewater systems: lessons learned from Austrian applications. Journal of Cleaner Production. 2015;88:125-31.

[148] Crawford GV. Best Practices for Sustainable Wastewater Treatment: Initial Case Study Incorporating European Experience and Evaluation Tool Concept. Water Intelligence Online. 2010;9:9781780407937.

[149] Ostapczuk RE, Bassette PC, Dassanayake C, Smith JE, Bevington G. Achieving Zero Net Energy Utilization at Municipal WWTPs: The Gloversville-Johnstown Joint WWTP Experience. Proceedings of the Water Environment Federation. 2011;2011:1191-200.

[150] Willis J, Stone L, Durden K, Beecher N, Hemenway C, Greenwood R. Barriers to biogas use for renewable energy. Barriers to biogas use for renewable energy. 2012.

[151] P P. Achieving energy independence at the Gresham wastewater treatment plant.

[152] Zabranska J, Dohanyos M, Kutil J, Jenicek P. Intensification of anaerobic digestion towards the energy self-sufficiency of municipal wastewater treatment. Water 21. 2009.

[153] Shi CY. Mass flow and energy efficiency of municipal wastewater treatment plants: IWA Publishing; 2011.

[154] Wiser J, Schettler J, Willis J. Evaluation of Combined Heat and Power Technologies for Wastewater Facilities. Atlanta. 2012. 
[155] Greer D. PIPELINE TRANSFER-DIRECTED BIOGAS TO POWER FUEL CELLS-A change in California's Public Utility Commission rule to allow injection of purified biomethane into natural gas pipelines opened the door for on-site power projects in San Diego. BioCycle-Journal of Composting and Recycling. 2011;52:47.

[156] Jolly M, Belshaw D, Telfer J. The biochemical relationships in anaerobic digestion after thermal hydrolysis at Davyhulme. Water and Environment Journal. 2014;28:459-72.

[157] Sheboygan Regional Wastewater Treatment Facility. http://www.sheboyganwwtp.com/files/2012/pdf/Treatment\%20Plant\%20Brochure\%202012.pdf. 2012.

[158] de Haas D, Foley J, Marshall B, Dancey M, Vierboom S, Bartle-Smith J. Benchmarking Wastewater Treatment Plant Energy Use in Australia. Ozwater'15 Conference2015. p. 12-4.

[159] Broda E. Two kinds of lithotrophs missing in nature. Zeitschrift für allgemeine Mikrobiologie. 1977;17:491-3.

[160] Mo W, Zhang Q. Energy-nutrients-water nexus: integrated resource recovery in municipal wastewater treatment plants. Journal of environmental management. 2013;127:255-67.

[161] Henriques J, Catarino J. Sustainable value-An energy efficiency indicator in wastewater treatment plants. Journal of Cleaner Production. 2017;142:323-30. 